\title{
A sourcebook on solitary confinement
}

Sharon Shalev 


\section{Copyright notice}

The right of Sharon Shalev to be identified as the author of this work has been asserted in accordance with the Copyright, Designs and Patents Act 1988. As we wish to encourage the widespread use of the Sourcebook, users are permitted to copy and distribute the material without having to seek formal permission or to pay a fee, provided that:

- The material is reproduced accurately and not in a misleading context

- The material is correctly acknowledged and the author's name appears on the work or the excerpt

- A copy of the publication containing the material is sent to the author

- No charge shall be made for the copy containing the work or the excerpt

No translation of the material may be produced without the expressed permission of the author.

Electronic copies of this report can be downloaded from the Solitary Confinement website, www.solitaryconfinement.org 


\section{A sourcebook on solitary confinement}

Sharon Shalev

Mannheim Centre for Criminology London School of Economics and Political Science Houghton Street, London WC2A 2AE, UK 


\section{Acknowledgments}

This project would not have been possible without the assistance of the Nuffield Foundation. Their support has been generous and unstinting.

Particular thanks are due to Jonathan Beynon and Monica Lloyd, who helped shape the Sourcebook from its early stages to its final form and contributed to the drafting of particular sections. Hernan Reyes and Camille Giffard also deserve a special mention for their extensive and perceptive comments on later drafts.

Many others have given generously of their time during the preparation of this Sourcebook by sharing their expertise, providing practical and professional insight and by commenting on whole or part of drafts. Thanks are due to: Henrik Steen Andersen, Helen Bamber, Jamie Bennett, Francesca Cooney, Andrew Coyle, Kimmett Edgar, Neil Frazer, John Gale, Dougie Graham, Andy Flynn and the Mental Health Team at Woodhill CSC, Stuart Grassian, Adrian Grounds, Craig Haney, Alison Hannah, Morit Heitzler, Lucy Kralj, Juliet Lyon, Clive Meux, Marlies Morsink, Lars Moller, Mary Murphy, Patrick Owen, Paul Rock, Peter Scharff-Smith, Julian Sheather and Ann Somerville.

Views expressed in the Sourcebook and any errors made in it are my own.

\section{Sharon Shalev}

October 2008 


\section{Preface}

The wide use of solitary confinement in prisons and other places of detention has long been a source of grave concern to those involved with the international protection of human rights. Never more so than in recent years, which have seen a marked increase in the use of strict and often prolonged solitary confinement across the world: in the context of the 'war on terror'; as disciplinary punishment; with pre-trial detainees, the mentally ill and former death-row prisoners; and, in the so-called 'supermax' prisons.

As this sourcebook clearly demonstrates, solitary confinement has a well documented negative impact on mental health and wellbeing and may amount to cruel, inhuman or degrading treatment or punishment, particularly when used for a prolonged time. The use of solitary confinement should therefore be strictly limited to exceptional cases or where it is absolutely necessary for criminal investigation purposes. The severe suffering caused by solitary confinement means that in all cases it should only be used as a last resort, and then for the shortest possible period of time. When used for interrogation purposes, either in combination with other methods or on its own, solitary confinement can amount not only to cruel, inhuman or degrading treatment but even to torture.

This comprehensive sourcebook brings together the accumulated knowledge and standards relating to solitary confinement and its harmful consequences. It identifies how solitary confinement may be misused and the protections that should be put in place. It is a valuable resource for prison staff and policy makers in the effort to promote the respect and protection of the rights and wellbeing of prisoners and detainees. Let us not forget that persons deprived of liberty are among the most vulnerable human beings in every society.

Solitary confinement has not received the attention it merits in international standards. There is a need to further develop protections aimed specifically at reducing its use and mitigating the harm it causes. The Sourcebook on Solitary Confinement is thus an important contribution in a shared endeavour that seeks the universal protection of human rights in all places of deprivation of liberty. I commend it to a wide readership.

Univ. Prof. Dr. Manfred Nowak, LL.M.

Professor for International Human Rights Protection, University of Vienna

Director, Ludwig Boltzmann Institute of Human Rights

UN Special Rapporteur on Torture 


\section{Contents}

1 Introduction 1

1.1 What is the Sourcebook about? $\quad 1$

1.2 How is the Sourcebook structured? $\quad 1$

1.3 Definition: what constitutes solitary confinement? 2

1.4 Brief historic context 2

1.5 Legal and regulatory framework 3

2 The health effects of solitary confinement 9

2.1 Introduction 9

2.2 The health effects of solitary confinement: a brief review of the literature and $\begin{array}{ll}\text { prisoners'accounts } & 10\end{array}$

2.3 The negative health effects of solitary confinement: reported symptoms 15

2.4 What makes solitary confinement harmful? 17

$\begin{array}{lll}2.5 & \text { The duration of solitary confinement } & 21\end{array}$

2.6 Sequelae of isolation: the lasting effects of solitary confinement 22

2.7 Concluding remarks about the effects of solitary confinement 23

3 The decision to place prisoners and detainees in solitary confinement 25

3.1 When and why are prisoners and detainees placed in solitary confinement? 25

3.2 Placement in solitary confinement: procedural safeguards, and special provisions and recommendations regarding the isolation of specific categories of prisoners 28

3.3 The human rights position and case law regarding the placement of prisoners in solitary confinement 
4.1 Introduction

4.2 International standards regarding prison conditions and regime

4.3 Research findings and recommendations regarding prison design and environmental factors

4.4 Human rights case law regarding regime and physical conditions in segregation units

4.5 Concluding remarks on regime and conditions of confinement in segregation and high security units

5 The role of health professionals in segregation units: ethical, human rights and professional guidelines

5.1 Introduction: ethics as applied to prison medicine

5.2 Issues regarding prison medicine in solitary confinement units

5.3 Case law regarding the provision of medical care in prison

Selected texts

\section{Appendix 2}

The Istanbul statement on the use and effects of solitary confinement 



\section{1 | Introduction}

\subsection{What is the Sourcebook about?}

Isolation, segregation, separation, cellular or solitary confinement are some of the terms used to describe a form of confinement where prisoners are held alone in their cell for up to 24 hours a day, and are only allowed to leave it, if at all, for an hour or so of outdoor exercise. Solitary confinement may be imposed on prisoners as short-term punishment for prison offences, or indefinitely for the prisoner's own protection, either at his request or at the discretion of the prison authorities. In other cases prisoners may be isolated from others for months and even years on administrative grounds: as a long-term strategy for managing challenging prisoners or where prisoners are deemed to be a threat to national security. Finally, pre-charge and pre-trial detainees may be isolated from others whilst their interrogation or the investigation into their case is ongoing.

This Sourcebook provides a single reference point for those concerned with the practice of solitary confinement, particularly when it is imposed for prolonged periods of time. Its purpose is to a) inform prison operational staff, health professionals, and policy makers of the human rights position regarding solitary confinement, of ethical and professional standards and codes of practice relating to prisoner isolation, and of research findings on the health effects of solitary confinement, and b) propose safeguards and best practice in light of the above. More broadly, it aims to raise awareness of the potential consequences of prolonged solitary confinement.

The basic premise in compiling this Sourcebook is that prolonged solitary confinement is inherently damaging and is not good practice. It should only be used as a last resort and be reserved for a handful of the most extreme cases. In the few cases where solitary confinement may be exceptionally and absolutely necessary, it should only be used for the shortest possible time, and be managed within established guidelines and strict safeguards. By extension, prison regimes which are entirely constructed around a solitary confinement model cannot but be damaging to prisoners and run contrary to principles of rehabilitation and social reintegration. While prison authorities may sometimes need to resort to short term disciplinary segregation, it must, again, only be as a last resort and managed within strict safeguards. The use of solitary confinement as a means of coercing a 'confession' or as means of 'softening up' detainees for interrogation must be prohibited under all circumstances.

\subsection{How is the Sourcebook structured?}

The rest of this chapter addresses issues of definition, provides the historic context for the use of solitary confinement, and sets out the legal and regulatory framework for the operation of prisons and the treatment of prisoners. Chapter Two examines the documented health effects of solitary confinement, both physical and psychological, and attempts to understand what makes solitary confinement damaging. Chapter Three examines the different roles of solitary confinement in 
contemporary prison systems - as punishment, for the prisoner's own protection, as a tool for managing difficult prisoners and as part of the investigation or interrogation process - and some of the standards, safeguards and recommendations relating to the placement of prisoners and detainees in solitary confinement. Chapter Four examines international standards, research findings and recommendations regarding the design, physical conditions and regime in isolation units. Chapter Five addresses some of the ethical issues and dilemmas facing health professionals working in solitary confinement units, and Chapter Six briefly examines international, regional and national mechanisms for inspecting and monitoring solitary confinement units. Chapter Seven recaps some of the main issues and themes discussed throughout the Sourcebook.

\subsection{Definition: what constitutes solitary confinement?}

For the purpose of the Sourcebook, solitary confinement is defined as a form of confinement where prisoners spend 22 to 24 hours a day alone in their cell in separation from each other'. Notwithstanding the different meanings attached to each of these terms in different jurisdictions, the term 'solitary confinement' will be used interchangeably with the terms 'isolation' and 'segregation' when describing regimes where prisoners do not have contact with one another, other than, as is the case in some jurisdictions, during an outdoor exercise period ${ }^{2}$.

\subsection{Brief historic context}

Solitary confinement is one of the oldest and most enduring prison practices. Bar the death penalty, it is also the most extreme penalty which can legally be imposed on prisoners. Solitary confinement was first widely and systematically used on both sides of the Atlantic in the 'separate' and 'silent' penitentiaries of the 19th century, with the aim of reforming convicts. It was believed that once left alone with their conscience and the Bible, prisoners would engage in inner reflection, see the error of their ways and be reformed into law abiding citizens. It soon transpired, however, that rather than being reformed, many prisoners became mentally ill, and there was little evidence that the newly built, expensive prisons were more successful than their predecessors in reducing offending. Such criticisms, combined with growing prison populations and pressures for additional prison spaces, led to the dismantling of the isolation system in most countries by the late 19th century ${ }^{3}$. By then, however, solitary confinement had become a permanent feature of prison systems world-wide, used mainly as a form of short term punishment for prison offences, for holding political prisoners, for protective custody, and as a technique for 'softening-up' detainees, particularly those suspected of crimes against the State, before and between interrogation sessions.

In addition to these 'traditional' uses, towards the end of the $20^{\text {th }}$ century and at the beginning of the $21 \mathrm{st}$, the use of long term, large scale solitary confinement returned in the form of 'supermax' (short for super-maximum security) and 'special security' prisons. These are large, high tech prisons, designed for long term and strict isolation of prisoners classified as high risk and/or difficult to control. This phenomenon is particularly evident in the United States, where the Federal Government and some 44 States operate at least one such prison, but similar units can now also 
be found in other countries. The use of prolonged solitary confinement has also increased in recent years in the context of the 'war on terror', not least at Guantanamo Bay where detainees have been held in supermax-like facilities for years, for the most part without any charge and without trial, and in secret detention centres where isolation is used as an integral part of interrogation practices ${ }^{4}$. Another form of solitary confinement, favoured in a number of European countries, is 'small group isolation' wherein prisoners who are classified as dangerous or high risk are held in solitary confinement in small high security units, and allowed limited association with one to five others at designated times, typically during the one-hour long outdoor exercise period required under international law. Paradoxically, although prison overcrowding is a major issue in many jurisdictions, the use of various forms of solitary confinement has increased in the last two decades.

\subsection{Legal and regulatory framework}

The operation of prisons and other places of detention, and the treatment of those held in them, are regulated by national laws, standards and directives, which vary from State to State. Such national instruments must also, however, be compatible with both international and regional human rights standards and laws ${ }^{5}$ as established by the United Nations and regional standard setting bodies (such as the Council of Europe, the Organisation of American States, the African Union etc.).

The Sourcebook draws on international and regional human rights instruments and their interpretation by the courts and monitoring bodies. It also draws on standards set by professional bodies to guide those working with prisoners. The Sourcebook does not, however, aim to provide a comprehensive review of human rights law and practice, but rather to address some of the most pertinent issues relating to solitary confinement ${ }^{6}$. Some of the key human rights instruments and bodies which are referred to throughout the Sourcebook are briefly introduced below, and Appendix 1 contains selected texts with which readers are encouraged to familiarise themselves. These resources are 'living instruments' which evolve over time, and the Sourcebook reflects current views and directives.

\section{Human rights instruments and bodies}

International human rights law includes both instruments designed for the universal protection of all human beings, and those designed specifically for the protection of prisoners and detainees. The basic premise of these instruments is that, other than limitations inherent in the deprivation of liberty, prisoners retain their human rights whilst incarcerated. These rights include, for example, the right to a free and fair trial; the right to freedom of thought, conscience and religion; the right to a private and family life; the right to adequate food, shelter and clothing; the right to health; and, the right to education.

The right of prisoners to be treated in a manner respectful of their human dignity and the prohibition against all forms of torture, inhuman or degrading treatment or punishment are reaffirmed in a large number of human rights instruments, including two international treaties, the International Covenant on Civil and Political Rights (ICCPR) and the UN Convention Against Torture (CAT) which are legally binding on all signatory parties to them, and parallel regional instruments. Additional instruments lay out rules of conduct for prison officers, health and other 
personnel, and set acceptable minimum standards for prison design, provisions and conditions. These include the UN Standard Minimum Rules for the Treatment of Prisoners (SMR), discussed below, and the Body of Principles for the Protection of All Persons under Any Form of Detention or Imprisonment?

\section{A. International human rights instruments and bodies}

\section{The International Covenant on Civil and Political rights (ICCPR)}

The ICCPR came into force in 1976. Its provisions are interpreted and its implementation monitored by the UN Human Rights Committee (HRC). Under Article 40 of the ICCPR, all State parties to it are required to submit a report on their compliance with the ICCPR initially upon ratification, and periodically thereafter. In addition, under the Covenant's Optional Protocol, the Human Rights Committee may consider individual communications from nationals of signatory states to the Protocol.

Two articles of the ICCPR relate directly to the treatment of prisoners and prison conditions, including solitary confinement. Article 7 of the ICCPR proclaims that "No one shall be subjected to torture or to cruel, inhuman or degrading treatment or punishment... ..

The Human Rights Committee has interpreted Article 7 to mean ${ }^{8}$ :

[2] The aim of the provisions of Article 7 is to protect both the dignity and the physical and mental integrity of the individual... [3] The text allows no limitation, even in time of public emergency...no justification or extenuating circumstances may be invoked to excuse a violation of Article 7 for any reason. [4] [The Committee] does not consider it necessary to draw up a list of prohibited acts, or to establish sharp distinction between the different kinds of punishment or treatment; the distinction depends on the nature, purpose and severity of the treatment applied.

The terms cruel, inhuman or degrading treatment or punishment, "should be interpreted so as to extend the widest possible protection against abuses, whether physical or mental, including the holding of a detained or imprisoned person in conditions which deprive him, temporarily or permanently, of the use of any of his natural senses, such as sight or hearing, or of his awareness of place and the passing of time" (Note to Principle 6, Body of Principles). This interpretation would apply to some uses of solitary confinement, for example in dark, windowless or soundproofed cells. In such cases, solitary confinement may amount to inhuman or degrading treatment and sometimes even to torture ${ }^{9}$.

Article 7 is closely linked to Article 10 of the ICCPR, which proclaims that "All persons deprived of their liberty shall be treated with humanity and with respect for the inherent dignity of the human person ... the penitentiary system shall comprise treatment of prisoners the essential aim of which shall be their reformation and social rehabilitation". Solitary confinement, by definition, deprives the individual from human contact and social interaction, and therefore clearly runs contrary to this principle.

Together, articles 7 and 10 of the ICCPR set out a blanket protection of detainees from any form of ill-treatment. The Human Rights Committee stipulated that: 
Article 10(1) imposes on state parties a positive obligation ... thus, not only may persons deprived of their liberty not be subjected to treatment that is contrary to Article 7...but neither may they be subjected to any hardship or constraint other than that resulting from the deprivation of liberty; respect for the dignity of such persons must be guaranteed under the same conditions as that of free persons. Persons deprived of their liberty enjoy all the rights set forth, subject to the restrictions that are unavoidable in a closed environment. [4] treating all persons deprived of their liberty with humanity and respect for their dignity is a fundamental and universally applicable rule... this rule must be applied without distinction of any kind, such as race, colour, sex, language, religion, political opinion, national or social origin, property, birth or other status... ${ }^{10}$.

\section{The UN Convention Against Torture and other Cruel, Inhuman or Degrading Treatment or Punishment}

The Convention Against Torture was adopted by the UN General Assembly in 1984 and came into force in 1987. Article 1 of the Convention stipulates that:

For the purpose of this Convention, the term "torture" means any act by which severe pain or suffering, whether physical or mental, is intentionally inflicted on a person for such purposes as obtaining from him or a third person information or confession, punishing him for an act he or a third person has committed or is suspected of having committed, or intimidating or coercing him or a third person....

The implementation of the Convention by State parties is monitored by a body of independent experts, the Committee Against Torture (CAT). All State parties to the Convention are required to submit a report within a year of ratification, and periodically thereafter. The Committee considers these reports and publishes its findings. In 2006 the Optional Protocol to the CAT (OPCAT) came into force with the aim of preventing torture and other ill-treatment through a system of regular inspection visits to all places of deprivation of liberty. The OPCAT establishes both an international inspection body (the Sub-Committee for the Prevention of Torture) and a permanent national inspecting body (known as the National Preventative Mechanism).

\section{UN Standard Minimum Rules for the Treatment of Prisoners (SMR)}

The SMR were adopted by the UN Economic and Social Council in 1957'11, and set out principles and guidelines as to "what is generally accepted as being good principle and practice in the treatment of prisoners and the management of institutions" (SMR preamble). The SMR list a very specific set of guidelines for the treatment of offenders, ranging from basic food, shelter and exercise requirements to guidelines on prisoner classification and the provision of educational and vocational training. The SMR also clearly set out general principles, including Rule 60 which reaffirms that prisoners are entitled to respect due to their dignity as human beings, Rules $64 \& 65$ which reaffirm that prisoners should be imprisoned as punishment, not for punishment, and Rule 27 which affirms that prisons should operate with "no more restriction than is necessary for safe custody and well ordered community life". Rule 31 addresses solitary confinement directly in prohibiting placement in a dark cell and all cruel, inhuman or degrading punishments for disciplinary offences. Although the SMR are not strictly legally binding on States, they set out minimum standards and recommendations for the operation of prisons which are now widely accepted as the main universal guidance for the treatment of prisoners. This is evidenced by the fact that in some countries they have been enacted into law or form the basis for national prison regulations. 


\section{The UN Special Rapporteur on Torture}

An independent expert appointed by the UN Commission on Human Rights (now replaced by the Human Rights Council), who is mandated to report on the situation of torture anywhere in the world, regardless of whether or not the country is a signatory of the Convention Against Torture and other Cruel, Inhuman or Degrading Treatment or Punishment. Successive Rapporteurs have addressed the use of various forms of solitary confinement around the world, and have identified situations where its use constitutes cruel, inhuman or degrading treatment or punishment and sometimes even torture.

\section{B. Regional human rights instruments and bodies ${ }^{12}$}

\section{European Convention on Human Rights (ECHR)}

The European Convention on Human Rights was adopted by the Council of Europe in Rome in 1950 and came into force in 1953. The European Court of Human Rights (ECtHR) monitors compliance with the Convention by Member States.

The ECHR proclaims in its Article 3 that "No one shall be subjected to torture or to inhuman or degrading treatment or punishment."The prohibition of torture and ill treatment is absolute. States cannot derogate from it in times of war or other public emergency, and it is expressed in unqualified terms. The threshold which ill treatment has to attain in order to fall within the scope of Article 3 of the ECHR is a relative one; "It depends on all the circumstances of the case, such as the duration of the treatment, its physical or mental effects and, in some cases, the sex, age and state of health of the victim"13. Inhuman treatment "covers at least such treatment as deliberately causes severe suffering, mental or physical, which, in the particular

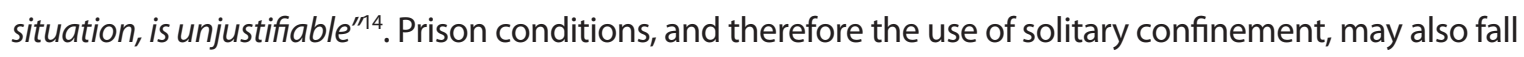
within the scope of Article 3. When assessing any one case the Court will take account of the cumulative effects of those conditions, as well as the specific allegations made by the applicant ${ }^{15}$.

\section{The European Prison Rules (EPR)}

The EPR ${ }^{16}$ contain 108 Rules, affirming that prisoners retain their human rights and setting detailed standards to guide the administration of prisons, prison conditions, the provision of health care in prisons, prison discipline, and the conduct of prison management and staff. Like the UN SMR, the EPR are not legally binding but they do set out minimum standards below which prison conditions must not fall.

\section{The Committee for the Prevention of Torture (CPT)}

The European Committee for the Prevention of Torture was created under Article 2 of the European Convention for the prevention of torture and inhuman or degrading treatment or punishment (1987), with a view to providing a non-judicial machinery of a preventive character and strengthening the protection of prisoners and detainees from torture or degrading treatment prohibited by Article 3 of the ECHR, through a system of visits. The CPT may visit any place where people are deprived of liberty within the jurisdiction of State parties. Through developing a set of standards which it applies when carrying-out visits to places of detention, the CPT also plays an important standard-setting role. 
1 Prison segregation should be distinguished from isolation or seclusion for medical purposes or in psychiatric settings, which are not discussed in this publication. The Sourcebook focuses mainly on adult, male prisoners and does not address issues relating specifically to other groups, such as women or young offenders.

2 The exercise period usually lasts for one hour, which is the minimum required by international law, but in some jurisdictions it may last up to two hours.

3 For an excellent account of the thinking behind the isolation prisons of the 19th Century see Evans, R. (1982) The Fabrication of Virtue: English prison Architecture 1750-1840. Cambridge: Cambridge University Press. See also: Morris, N. and Rothman, D., eds. (1998) The Oxford History of the Prison: The Practice of Punishment in Western Society. Oxford: Oxford University Press; Rothman, D.J. (1980) Conscience and Convenience: The Asylum and its Alternatives in Progressive America. Boston: Little, Brown and Company.

4 See Human Rights Watch report: Locked Up Alone: Detention Conditions and Mental Health at Guantanamo, June 2008.

5 Human rights laws include: treaty law (treaties, conventions, covenants), which is legally binding on States which are parties to it and on State agents, including prison officials; customary law, which reflects long established practices that are accepted as unwritten laws, and; human rights declarations, recommendations, principles, codes of conduct and guidelines, which are not in themselves legally binding but nonetheless reflect international norms and customs.

6 For a more general discussion of human rights and prisons see: Andrew Coyle (2002) A Human Rights Approach to Prison Management, International Centre for Prison Studies, London; Office of the United Nations High Commissioner for Human Rights (2005) Human Rights and Prisons, Professional Training Series No.11, available online at: www.ohchr.org

7 The Body of Principles was adopted the UN General Assembly in December 1988. It contains 39 principles reaffirming that prisoners and detainees retain their human rights when detained, and lists some of the procedural and substantial principles which should direct the operation of all places of detention universally. Other relevant human rights instruments include the Basic Principles for the Treatment of Prisoners (adopted in 1990, affirming that prisoners retain their fundamental human rights); UN Code of Conduct for Law Enforcement Officials; Principles of Medical Ethics; and, in situations of armed conflict, the Geneva Conventions of 1949 and their Additional Protocols of 1977.

8 General comment 20/44 of 3 April 1992.

9 See Reyes, H. The worst scars are in the mind: psychological torture, International Review of the Red Cross, Volume 89 No. 867 September 2007 pp 591-617.

10 United Nations Human Rights Committee General comment 21/44 of 6 April 1992, para. [3].

11 Adopted by the First United Nations Congress on the Prevention of Crime and the Treatment of Offenders, held in Geneva in 1955, and approved by the Economic and Social Council by its resolutions 663 C (XXIV) of 31 July 1957 and 2076 (LXII) of 13 May 1977.

12 The brief discussion in this chapter is based on European instruments and bodies, but similar provisions are made in other regional instruments including the American Convention on Human Rights (ACHR) which proclaims in its Article 5 that "(1) Every person has the right to have his physical, mental and moral integrity respected. (2)No one shall be subjected to torture or to cruel, inhuman or degrading treatment or punishment. All persons deprived of their liberty shall be treated with respect for the inherent dignity of the human person".

13 Ireland v UK A25 (1978) at par. 162

14 The Greek Case, 5.11.69, Yearbook of the European Convention on Human Rights, Vol. 12,1969, p186.

15 Dougoz v. Greece, no. 40907/98, 46, ECHR 2001-II

16 Council of Europe, Recommendation No R(87)3, revised and replaced by recommendation (2006)2. 


\section{$2 \mid$ The health effects of solitary confinement"}

\subsection{Introduction}

Being held in solitary confinement is, for most prisoners, a stressful experience with potentially harmful health effects. The prisoner is socially isolated from others, his human contacts reduced to superficial transactions with staff and infrequent contact with family and friends. He is almost completely dependent on prison staff - even more than is usual in the prison setting - for the provision of all his basic needs, and his few movements are tightly controlled and closely observed. Confined to a small sparsely furnished cell with little or no view of the outside world and with limited access to fresh air and natural light, he lives in an environment with little stimulation and few opportunities to occupy himself.

Throughout the long history of its use in prisons - from the 'silent' and 'separate' penitentiaries of the $19^{\text {th }}$ century through to modern-day segregation units and 'supermax' prisons - practitioners and researchers have observed the adverse effects of solitary confinement on prisoners' health. In the context of coercive interrogation, international experts have identified solitary confinement as psychological torture ${ }^{18}$. The potentially damaging effects of solitary confinement are also recognised by national and international instruments and by monitoring bodies, which view it as an extreme prison practice which should only be used as a last resort and then only for short periods of time. Indeed, expressing strong concern about the use of solitary confinement as punishment, in 1990 the United Nations went as far as to call for its abolition ${ }^{19}$.

This chapter examines some of the research findings on the health effects of solitary confinement dating back to the $19^{\text {th }}$ century, and attempts to explain how and why solitary confinement adversely affects physical, mental and social wellbeing ${ }^{20}$. Although negative health effects may emerge after a very short period of time in solitary confinement, this chapter is mostly concerned with the more serious health effects that are associated with longer periods of solitary confinement. 


\subsection{The health effects of solitary confinement: a brief review of the literature and prisoners' accounts}

\section{General observations}

There is unequivocal evidence that solitary confinement has a profound impact on health and wellbeing, particularly for those with pre-existing mental health disorders, and that it may also actively cause mental illness. The extent of psychological damage varies and will depend on individual factors (e.g. personal background and pre-existing health problems), environmental factors (e.g. physical conditions and provisions), regime (e.g. time out of cell, degree of human contact), the context of isolation (e.g. punishment, own protection, voluntary/ non voluntary, political/criminal) and its duration.

Notwithstanding variations in individual tolerance and environmental and contextual factors, there is remarkable consistency in research findings on the health effects of solitary confinement throughout the decades. These have mostly demonstrated negative health effects, with studies reporting no negative effects being few and far between, and virtually no study reporting positive effects ${ }^{21}$.

\section{Historic accounts}

The extensive use of solitary confinement in prisons of the early $19^{\text {th }}$ century was well documented, and its effects on prisoners reported in medical journals of the time. Grassian and Friedman (1986) cite thirty seven reports and articles published in Germany alone between 1854 and 1909, identifying solitary confinement as the single central factor in the development of psychotic illness among prisoners. Examples include an 1854 report by the chief physician of Halle prison, Germany, who observed what he termed Prison Psychosis among isolated prisoners and concluded that "prolonged absolute isolation has a very injurious effect on the body and mind and seems to predispose to hallucinations" and should therefore be immediately terminated (Nitsche \& Williams, 1913). A report from 1863 describes vivid hallucinations, delusions, apprehension and psychomotor excitation experienced by 84 prisoners suffering from what its authors termed the Psychosis of Solitary Confinement. In 1881, a summary of diagnostic assessments of 186 prisoners held at the 'insane department' at Waldheim prison, also in Germany, concluded that over half of the prisoners suffered reactive manifestations to solitary confinement (Grassian \& Friedman, 1986).

Similar observations were made in England, where in 1850 for example, 32 out of every 1000 prisoners had to be removed from their solitary cells in Pentonville prison on grounds of insanity, compared to 5.8 prisoners per 1000 in prisons not practising solitary confinement (McConville, 1981:208-9). In the US, the Boston Prison Discipline Society, which helped devise the 'Separate' or 'Pennsylvania' system of solitary confinement, reported from as early as 1839 serious mental problems amongst isolated prisoners, including hallucinations and dementia (cited in Scharff-Smith, 2004). Referring to similar reports several years later, the US Supreme Court noted that the effects of solitary confinement were such that " $a$ considerable number of prisoners.... fell into a semi-foetus condition... and others became violently insane" (Re Medley, 1890:167-8). Indeed, the understanding that instead of its intended role of helping to 'cure the disease of crime', solitary confinement was creating mental illness in prisoners, played a central role in the dismantling of the isolation prisons on both sides of the Atlantic by the late $19^{\text {th }}$ century. 
Yet, although the use of solitary confinement on a large scale ceased, it remained an integral part of prison systems and, as previously noted, in the last decade its use has increased in many jurisdictions. Throughout the decades researchers have continued to report negative effects associated with solitary confinement, and their findings are strikingly similar to those made by their historic counterparts.

\section{Contemporary findings}

More recent studies have mostly reaffirmed that solitary confinement adversely affects those subjected to it, and have identified "confinement psychosis" as a medical condition typified by "psychotic reaction characterised frequently by hallucinations and delusions, produced by prolonged physical isolation and inactivity in completely segregated areas" (Scott \& Gendreau, 1969:338).

A 1975 inquiry into the use of isolation in Canadian prisons concluded that administrative isolation over long periods of time represented a "serious danger for prisoners"22. Two years later a Council of Europe (1977) study suggested that prolonged close-confinement of long-term prisoners led to what was termed 'separation syndrome' that included emotional, cognitive, social and physical problems ${ }^{23}$. Benjamin \& Lux (1977:262) stated that "evidence overwhelmingly [indicates] that solitary confinement alone, even in the absence of physical brutality or unhygienic conditions, can produce emotional damage, decline in mental functioning and even the most extreme forms of psychopathology such as depersonalization, hallucinations and delusions". Ruling in a case involving prisoners held in strict isolation in Germany, the European Human Rights Commission (1978:97) similarly noted that "isolation can be sufficient in itself to gravely impair physical and mental health".

Grassian's (1983) psychiatric evaluation of 14 prisoners held in the solitary confinement block at the Massachusetts Correctional Institution at Walpole reported perceptual changes, affective disturbances, difficulty with thinking, concentration and memory, disturbances of thought content, and problems with impulse control. Korn's study (1988) of the women's High Security Unit at Lexington, Kentucky, found that women held there suffered claustrophobia, rage, severe depression, hallucinations, withdrawal, blunting of affect and apathy. He also reported appetite loss, weight loss, visual disturbances and heart palpitations. Brodsky \& Scogin's (1988) study of 45 prisoners held in protective custody similarly reported a high prevalence of negative physiological and psychological symptoms including nervousness, talking to oneself, hallucinations and delusions, confusion, irrational anger, headaches and problems sleeping. Hodgins \& Cote (1991) found severe mental disorders amongst 29 per cent of a sample of 41 segregated prisoners held in Quebec's Special Handling Unit (SHU), and in 31 per cent of a sample of 32 prisoners segregated in the Long-Term Segregation Unit (LTSU) ${ }^{24}$.

Haney's (1993) study of 100 randomly selected prisoners in one of California's supermax prisons, Pelican Bay Security Housing Unit, reported a very high prevalence of symptoms of psychological trauma with $91 \%$ of the prisoners sampled suffering from anxiety and nervousness, more than $80 \%$ suffering from headaches, lethargy and trouble sleeping and 70\% fearing impending breakdown. More than half of the prisoners suffered from nightmares, dizziness and heart palpitations and other mental-health problems caused by isolation, which included ruminations, irrational anger and confused thought processes (more than $80 \%$ of prisoners sampled), chronic depression (77\%), hallucinations (41\%) and overall deterioration. 
Miller's (1994:48) study of 30 prisoners in a Kentucky prison similarly found that "inmates housed in the most restrictive environment [punitive segregation] reported significantly higher levels of psychological distress symptoms such as anxiety and hostility, than inmates in the general population". A follow-up study (Miller \& Young, 1997:92) reported withdrawal, hostility, aggression, rage and irresistible impulses among those held in disciplinary segregation and concluded that these findings indicate that "there may be a level of restriction that, instead of solving administrative problems, becomes both a mental health issue and a further problem for the prison administration". Sestoft et al. (1998:105) concluded their study of the impact of solitary confinement on subsequent hospitalisation among Danish detainees by stating that "individuals in solitary confinement are forced into an environment that increases their risk of hospitalisation ... for psychiatric reasons".

In his extensive study on the effects of imprisonment on more than 900 prisoners, including those held in segregation units, Hans Toch coined the term "Isolation Panic"' to describe the experiences of isolated prisoners. Symptoms of this syndrome included

A feeling of abandonment ... dead-end desperation... helplessness, tension. It is a physical reaction, a demand for release or a need to escape at all costs... [Isolated prisoners] feel caged rather than confined, abandoned rather than alone, suffocated rather than isolated. They react to solitary confinement with surges of panic or rage. They lose control, break down, regress... (Toch 1992:49).

Harvard psychiatrist Stuart Grassian, who has been studying the effects of solitary confinement for over two decades, similarly suggested that the symptoms experienced by isolated prisoners form a distinct syndrome, closely akin to 'delirium',

That is, a constellation of symptoms occurring together and with a characteristic course over time, thus suggestive of a discrete illness... while this syndrome is strikingly atypical for the functional psychiatric illnesses, it is quite characteristic of an acute organic brain syndrome: delirium, characterised by a decreased level of alertness, EEG abnormalities ... perceptual and cognitive disturbances, fearfulness, paranoia, and agitation; and random, impulsive and self-destructive behavior ... (Grassian, 2006:338).

Finally, the growing body of research into the health effects of confinement in 'supermax' prisons in the United States (for example: Cloyes et al. (2006); Haney (2003); Kupers (1999); Miller (1994); Miller \& Young (1997); Rhodes (2004); Grassian, (2006).) largely confirms findings reported in earlier studies, namely, that "this experience is psychologically painful, can be traumatic and harmful, and puts many of those who have been subjected to it at risk of long-term emotional and even physical damage" (Haney\& Lynch, 1997:500).

\section{The accounts of prisoners}

Researchers have found that prisoners in solitary confinement often have little insight into their own mental state and tend to minimise their reaction to solitary confinement and play down any mental health problems (Grassian, 1983; Haney, 2003). Segregated prisoners also appear to have a more negative view of psychiatric treatment in prison and tend to avoid seeking such help (Coid et al. 2003-1:315). Mental health problems are particularly stigmatised amongst Muslim prisoners who are reluctant to seek help (Robbins et al. 2005). A report of the inspection of a small unit for Muslim prisoners detained under immigration law on the grounds of national security in the UK, for 
example, identified that five of the eight had significant mental health problems but that there was very little take up of the mental health service provided (An Inspection of the Category A Detainee Unit at Long Lartin, HMCIP, 2007). Nonetheless, accounts from prisoners themselves illustrate a range of severe adverse health effects. What follows is what has emerged from interviews with prisoners in isolation, or after the event, and from writings by formerly isolated prisoners.

One of the problems most commonly reported by prisoners who were isolated is that they found it hard to distinguish between reality and their own thoughts, or found reality so painful that they created their own fantasy world. Researchers link such incidents to the absence of external stimuli which results in the brain starting to create its own stimulation, manifesting in fantasy and hallucinations. One study of prisoners who were isolated for periods ranging from 11 days to 10 months reported both auditory and visual hallucinations. One interviewee described how: "the cell walls start wavering... everything in the cell starts moving; you feel that you are losing your vision". Others reported auditory hallucinations: "I overhear guards talking. Did they say that? Yes? No? It gets confusing. Am I losing my mind?" Prisoners also reported high sensitivity to noise and smells: "you get sensitive to noise. The plumbing system... the water rushes through the pipes- it's too loud, gets on your nerves. I can't stand it. Meals- I can't stand the smells....the only thing I can stand is the bread" (Grassian, 1983).

Other studies have reported similar experiences, ranging from hypersensitivity to sound and smell, to paranoid episodes and self-injury. One former female prisoner described extreme sensitivity to sounds "Your vision was highly restricted, so you live by sound... you could hear every creaking of the place, you know, the building. It was almost amplified... not that our hearing was better, it was just that we paid more attention because sound had to do with... with life" (Cited in Shalev, forthcoming). Another former prisoner who was isolated in a dark punitive isolation cell 'saw faces' and 'held conversations' with people who were not there:

Sometimes I felt like I was losing my mind, or that I have lost it already, you know... Holding conversations with myself... I had conversations with people. I mean dialogues, long dialogues with people. Some of them I knew, and some of them I didn't know. There were times when the darkness wasn't dark. I could see faces... I think that I found out that I may be hallucinating when I touched my eyes and my eyes were open so I kind of knew I wasn't dreaming. After a while I thought that maybe I will die there. I really thought I would [Former prisoner, USA, cited in Shalev, forthcoming].

Similar findings were reported by Siegel's (1984) study of 31 people who were subjected to isolation, visual deprivation and restraint on physical movement as hostages, prisoners of war or convicted prisoners over varying periods. All interviewees reported visual and auditory hallucinations that appeared within hours of being isolated and became more and more elaborate as time went by. Prisoners participating in Toch's (1992) large-scale study of the psychological effects of incarceration reported similar experiences in solitary confinement. Interviewee ' $M$ ', for example, described panic and paranoid thoughts during his first days in isolation:

... and then I lay on the mattress, and then after I sit there I feel the walls coming in around me. And then when the guards come in and I am screaming, they say: 'what the fuck is going on here?' and I say 'the walls are closing in on me' and they say 'that's tough, you're going to die anyway. We'll strangle you'.. I was thinking that if I don't get the hell out of there, they're going to kill me. And I don't feel like fighting them (Toch 1992:150). 
Another former prisoner who spent two years in a supermax prison in California chose to refer to 'seeing others lose it' and described similar scenarios ${ }^{25}$ :

I have seen inmates lose their mind completely because of the sound of a light where they are yelling at the light, cursing at the light, believing that for some reason the [authorities] planted some kind of noise inside the light purposely... and so the inmates that ain't strong minded, don't have something to hang on to, the light, the sound of the door, can make them lose their mind... I found it strange, you know, how can a grown man, a very big, grown man, break down to a light. But that's what [that place] can do. And once you lose your mind, you don't know right from wrong. You don't know that you're breaking a rule. You don't know what to do exactly [Former prisoner, USA, cited in Shalev forthcoming].

Seeing and hearing other prisoners break down is a stressful experience in itself, as Henry Charriere ('Papillon') found during his time in isolation on 'Devil's Island', a French penal colony in Guyana: "A great many suicides and men going raving mad around me... it's depressing to hear men shouting, weeping or moaning for hours or even days on end". He himself survived eight years in solitary confinement through fantasy: "thanks to my wandering amongst the stars it was very rare that l ever had a lasting despair. I got over them pretty fast and quickly invented a real or imaginary voyage that would dispel the black ideas" (1970:354-356). One of the problems with such techniques is that the boundaries between fantasy and reality can become dangerously blurred, as was the case for one former female prisoner, who regularly 'left her body' to 'travel' in the outside world. These were not daydreams, but out-of-body experiences from which at times, according to her, it was "really hard to come back":

The first four years of prison was such a fantasy world... I was in segregation. I could be in my cell and shut everyone out and I would go travelling. I would go up and out of prison and fly over the beaches and mountains of Okinawa, where I used to live. Sometimes it was really, really hard to come back [Former prisoner, USA, cited in Shalev, forthcoming].

As her time in isolation grew longer, so did the intensity and frequency of her 'travels', until one day the prison chaplain saw her lying on her cell-floor in a near catatonic state and took her under his wing. British prisoner Doug Wakefield had somewhat less pleasant hallucinations after a period in isolation, "usually in the form of spiders and insects crawling over the floor, the bed and walls, and at such times it is common to hear voices and strange noises" (Wakefield 1980:28). Describing himself as a 'graduate of 1000 days in segregation', he wrote: "fantasising and day-dreaming become prevalent pastimes and the obvious danger here is that this activity could become a permanent feature of the mind with the consequent disadvantage of not knowing at times whether you are in reality or fantasy" (Ibid at p. 30).

The similarities between these accounts of time in isolation in different contexts, geographical locations, and for varying periods of time are striking and cannot be easily discounted. Further, the personal accounts cited above are consistent with research findings on the health effects of solitary confinement reviewed previously. Some of the reported health effects of solitary confinement, both physiological and psychological, are listed in the following section. 


\subsection{The negative health effects of solitary confinement: reported symptoms}

\section{Physiological effects}

Although psychological effects are most common and usually dominant, physiological effects are nevertheless commonly reported. Some of these may be physical manifestations of psychological stress, but the lack of access to fresh air and sunlight and long periods of inactivity are likely also to have physical consequences. Grassian and Friedman (1986) list gastro-intestinal, cardiovascular and genito-urinary problems, migraine headaches and profound fatigue. Other signs and symptoms recorded by the some of the studies reviewed above are

- Heart palpitations (awareness of strong and/or rapid heartbeat while at rest)

- Diaphoresis (sudden excessive sweating)

- Insomnia

- Back and other joint pains

- Deterioration of eyesight

- Poor appetite, weight loss and sometimes diarrhoea

- Lethargy, weakness

- Tremulousness (shaking)

- Feeling cold

- Aggravation of pre-existing medical problems.

\section{Psychological effects}

The most widely reported effects of solitary confinement are its psychological effects ${ }^{26}$. These will vary with the pre-morbid adjustment of the individual and the context, length and conditions of confinement. The experience of previous trauma will render the individual more vulnerable, as will the involuntary nature of confinement as punishment, and confinement that persists over a sustained period of time. Initial acute reactions may be followed by more chronic symptoms if the confinement persists. While the majority of those held in solitary confinement will report some form of disturbance, there may be a small number of prisoners who show few signs and symptoms and may be more resilient to the negative effects of solitary confinement. Symptoms occur in the following areas and range from acute to chronic.

Anxiety, ranging from feelings of tension to full blown panic attacks

- Persistent low level of stress

- Irritability or anxiousness

- Fear of impending death

- Panic attacks 
Depression, varying from low mood to clinical depression

- Emotional flatness/blunting - loss of ability to have any 'feelings'

- Emotional lability (mood swings)

- Hopelessness

- Social withdrawal; loss of initiation of activity or ideas; apathy; lethargy

- Major depression

Anger, ranging from irritability to full blown rage

- Irritability and hostility,

- Poor impulse control

- Outbursts of physical and verbal violence against others, self and objects

- Unprovoked anger, sometimes manifesting as rage

Cognitive disturbances, ranging from lack of concentration to confusional states

- Short attention span

- Poor concentration

- Poor memory

- Confused thought processes; disorientation.

Perceptual distortions, ranging from hypersensitivity to hallucinations

- Hypersensitivity to noises and smells

- Distortions of sensation (e.g. walls closing in)

- Disorientation in time and space

- Depersonalisation/derealisation

- Hallucinations affecting all five senses, visual, auditory, tactile, olfactory and gustatory (e.g. hallucinations of objects or people appearing in the cell, or hearing voices when no-one is actually speaking).

Paranoia and Psychosis, ranging from obsessional thoughts to full blown psychosis

- Recurrent and persistent thoughts (ruminations) often of a violent and vengeful character (e.g. directed against prison staff)

- Paranoid ideas - often persecutory

- Psychotic episodes or states: psychotic depression, schizophrenia. 


\section{Self-harm and suicide}

Historical reports of $19^{\text {th }}$ Century isolation prisons repeatedly describe acts of auto-aggression, selfmutilation, and suicide. Contemporary studies have also shown that self-harm (including banging one's head against the cell wall) and suicides are more common in isolation units than in the general prison population (Haney \& Lynch 1997:525). In California, for example, a reported $69 \%$ of prison suicides in 2005 occurred in segregated housing units (USA Today, 27/12/2006), and in England and Wales in 2004/5 a fifth of prison suicides took place in segregation units (National Offender Management Service, Safer Custody Group. Self inflicted deaths Annual Report, 2004/5).

Other forms of self-harm are also prevalent in solitary confinement. Researchers have noted that self-mutilation or cutting is often "a result of sudden frustration from situational stress with no permissible physical outlet... Self-addressed aggression forms the only activity outlet" (Scott \& Gendreau, 1969:341). Another study found that self-mutilation was a means to "liberate the self from unbearable tension- the physical pain becomes a compensatory substitute for psychic pain or shame" (Dabrowski (1937), cited in McCleery, 1961:303). Former prisoners have testified that self harm played another role for them when they were held in segregation - it asserted that they were still alive.

I was totally frustrated... I started smashing up the cell. I refused to eat. I started refusing water. I was totally paranoid. I started sipping my own urine because I thought they were trying to poison me. I resorted to self-injury, was put in a body belt. You become so angry. It's an outlet, but you have to vent it out. Even your own blood is something real [Former prisoner, UK, cited in Shalev, forthcoming].

I found myself curled up in a foetal position rocking myself back and forth and banging my head against the wall. In the absence of sensation, it's hard sometimes to convince yourself that you're really there [Former prisoner, US, cited ibid.].

It is difficult to obtain figures for forms of self-harm that do not result in death. Nonetheless, there is compelling anecdotal evidence that the prevalence of such incidents in segregation and isolation units is particularly high.

\subsection{What makes solitary confinement harmful?}

Each of the three main factors inherent in solitary confinement- social isolation, reduced environmental stimulation and loss of control over almost all aspects of daily life- is potentially distressing. Together they create a potent mix. Moreover, psychiatric morbidity studies of prisoners indicate that they are a particularly vulnerable population, even when not in solitary confinement. In England and Wales, a morbidity survey of prisoners carried out by the Office for National Statistics in 1998 found that only 10\% were without any history of neurotic disorder, psychotic disorder, personality disorder or substance misuse, and many experienced some or all of these in combination (ONS psychiatric morbidity survey, 1998). It is also known that about $7 \%$ of prisoners have a severe learning disability, with an IQ of 70 or below ${ }^{27}$, and that those with learning disabilities find it particularly difficult to cope with isolation. About $12 \%$ will also be receiving psychiatric treatment while in prison for severe and enduring mental illness (HMCIP, The mental health of Prisoners, 2007). One cause of these high levels of disturbance is the experience of early life trauma 
and the resulting poor personal and social adjustment. All these features conspire to render prisoners particularly vulnerable to the effects of isolation, reduced activity, under-stimulation and loss of control over their lives.

Conversely, anecdotal evidence suggests that some prisoners are protected from the worst impact of solitary confinement by the meaning they are able to make of the experience. Some political prisoners, for example, have demonstrated remarkable resilience during prolonged periods of confinement. That does not mean that the experience was not a difficult one. Describing his time in Robben Island, Nelson Mandela writes: "I found solitary confinement the most forbidding aspect of prison life. There is no end and no beginning; there is only one's mind, which can begin to play tricks. Was that a dream or did it really happen? One begins to question everything." (Nelson Mandela, The Long Walk to Freedom, 1995). Leaders of the Tupamaro movement in Uruguay, who were imprisoned in strict solitary confinement (they were not allowed to communicate with anyone, meals were delivered to them through a hatch in the cell-door by guards who were instructed not to exchange a word with them) for several years during the 1970's, reported that solitary confinement was the worst form of torture; one prisoner said that "electricity [torture] is mere child's play in comparison to prolonged solitude" (cited in Reyes, 2007:607).

\section{Social isolation}

Social well-being is seen by the World Health Organisation as integral to its definition of 'health'28. Solitary confinement removes the individual from the company of others and deprives him or her of most forms of meaningful ${ }^{29}$ and sympathetic social interaction, as well as physical contact. In most cases the isolated individual is deprived of any form of interaction with fellow prisoners, and sometimes with family and friends through restrictions on visits. Where visits do take place they can be closed, with a barrier separating the prisoner from his visitors, preventing any physical contact between them.

Social learning theories highlight the importance of social contact with others not just for pleasure and play but for the individual's very sense of 'self' which is shaped and maintained through social interactions. Social contact is crucial for forming perceptions, concepts, interpreting reality and providing support ${ }^{30}$.

The self... is essentially a social structure and it arises in social experience. After a self has arisen, it in a certain sense provides for itself its social experiences, and so we can conceive of an absolutely solitary self. But it is impossible to conceive of a self arising outside social experience. When it has arisen we can think of a person in solitary confinement for the rest of his life, but who still has himself as a companion, and is able to think and to converse with himself as he had communicated with others.... This process of abstraction cannot be carried on indefinitely. (Mead, 1934, emphasis added).

Paradoxically, social isolation can lead to further withdrawal. One study found support for the hypothesis that the "shut-in" or "seclusive" personality, "generally considered to be the basis of schizophrenia, may be the result of an extended period of 'cultural isolation', that is, separation from intimate and sympathetic social contact" (Faris, 1962:155). Faris adds that "seclusiveness is frequently the last stage of a process that began with exclusion or isolation which was not the choice of the patient" (lbid. at p. 159). 
Deprived of meaningful and sympathetic social contact and interaction with others, the prisoner in solitary confinement may withdraw and regress. Even when isolated prisoners do not show any obvious symptoms, upon release from isolation they can become uncomfortable in social situations and avoid them, with negative consequences for subsequent social functioning in both the prison community and the outside community, again undermining the likelihood of successful resettlement.

\section{Reduced activity and stimulation}

Monotony and reduced sensory stimulation are part and parcel of the experience of isolation. In the isolation prisons of the $19^{\text {th }}$ century, where prisoners had access to work, great care was taken to ensure that they were given intentionally tedious and dull jobs usually performed in silence. In 'modern' isolation sections of prisons, work, education or other diversion such as reading material, radio or television, can be withheld or restricted as part of a system of punishment. When work is allocated, it is often conducted inside the cell and, as in the 19th century, can be simple and monotonous, for example stuffing envelopes. Prisoners can be detained in sparsely furnished cells for up to 23 hours a day with little sensory or mental stimulation.

Prisoners' accounts illustrate the effects of monotony and boredom on their mental state during a period of isolation:

Boredom is a major enemy. Sensory deprivation is a way of life. There is simply nothing to do. Sit in your bathroom alone with none of your intimate possessions and try to imagine years of it, week after week. Slowly it tears you down, mentally and physically ${ }^{31}$.

The utter and monstrous boredom that becomes so obvious after a short period of isolation is an all-powering one... in order to fight off the tendency to complete idleness and to retain a hold on the senses, it is necessary to make great exertions... Yet no matter how successful a prisoner may be in staving off the effects of... isolation, it is only a matter of time before it catches up with him (Wakefield 1980:28).

...you sit in solitary confinement stewing in nothingness, not merely your own nothingness but the nothingness of society, others, the world. The lethargy of months that add up to years in a cell, alone, entwines itself about every 'physical' activity of the living body and strangles it slowly to death, the horrible decay of the truly living death. You no longer do push-ups or other physical exercise in your small cell; you no longer pace the four steps back and forth across you cell. You no longer masturbate; you can call forth no vision of eroticism in any form... time descends in your cell like the lid of a coffin in which you lie and watch it as it slowly closes over you... solitary confinement in prison can alter the ontological makeup of a stone (Abbott 1982:44-45).

These personal accounts are supported by studies which indicate that reduced sensory input may lead to reduced brain activity. Building on the input-output theory, one study suggested that sensory input and motor-mental output work in parallel: 
A drop in sensory input through sensory restriction produces a drop in mental alertness, an inability to concentrate, a drop in planning and motivation, together with a drop in physical activity in the speech and motor systems... In prison life boredom generates boredom. A drop in stimulus input results in mental sluggishness, a disinclination to learn and a correlated drop in planning, motivation and physical activity (Scott \& Gendreau, 1969:338).

To evaluate this hypothesis, the brain activity of isolated prisoners was measured daily. Researchers found that following seven days in isolation there was a decline in brain activity. This decline "was correlated with apathetic, lethargic behaviour... and with a reduction in stimulation seeking behaviour. Up to seven days the EEG decline is reversible, but if deprived over a long period this may not be the case" (Scott \& Gendreau, ibid.).

\section{Lack of control}

A third aspect of segregated confinement is the rigid regime and exceptionally high level of control over all aspects of prisoners' lives, or what has been termed "an authoritarian system of social control" (McCleery, 1961:272), or the "totality of control" (Haney, 1993).

While undergoing any special control or disciplinary measure, some degree of increased control and watchfulness from the authorities is inevitable. However, in the case of solitary confinement, this control is extreme and prisoners have few avenues or areas where they can exercise personal autonomy, and are completely dependent on staff for the provision of all their basic needs. When this degree of control is exercised over long periods of time, the psychological impact is proportionally greater.

Various studies have examined the socio-psychological aspects of long-term imprisonment in highly controlled environments and have identified some common psychological reactions ${ }^{32}$. These typically range from apathy to aggression: "either reaction to the system of rigid discipline tends to become something very much like insanity - apathy, listlessness, vagaries, or else irritability, hatred and nervous instability" (Sutherland \& Cressey, 1955:473). Another study similarly noted that over time, symptoms experienced by isolated prisoners are "likely to mature into either homicidal or suicidal behaviour" (McCleery, 1961:265).

Thus, contrary to the aims of enforcing calm and control on a prisoner, solitary confinement can produce further irritability and even violent outbursts, often unprovoked. Such violent outbursts may be directed against staff, but may also be turned upon the prisoner himself in the form of selfharm or suicide. Where the prisoner does become more docile and apparently conforming to the rules, it may in fact be a pathological reaction in the form of withdrawal, emotional numbing and apathy. Further, the 'totality of control' means that some prisoners become so reliant on the prison to organise their lives and daily routines that they lose the capacity to exercise personal autonomy. This, again, may render them dysfunctional in society upon their release and some will seek to return to prison. 


\subsection{The duration of solitary confinement}

All studies of prisoners who have been detained involuntarily in solitary confinement in regular prison settings for longer than ten days have demonstrated some negative health effects (Haney, 2003), and even apologists of the practice agree that prolonged punitive solitary confinement "presents considerable risk to the inmates" (Gendreau and Bonta, 1984:475).

A study comparing subsequent admission to psychiatric hospitals in Denmark for prisoners held in solitary confinement compared to those held with other prisoners, found that hospitalisation rates diverged significantly after four weeks. The "probability of being admitted... for psychiatric reasons was about 20 times as high as for a person remanded in non-solitary confinement for the same period of time" (Sestoft et al. 1998:105). Siegel's (1984) study of 31 people who were subjected to isolation, visual deprivation and restraint on physical movement in different situations (hostages, POWs, prisoners) and for varying times reported visual and auditory hallucinations within hours of being isolated, becoming more severe with time.

Studies with volunteer prisoners isolated for periods of up to ten days have commonly reported minimal negative effects. Walters et al (1963:772) noted that for 20 long-term prisoners in a Canadian Federal Penitentiary who volunteered to stay in solitary cells for four days "while social isolation may produce some change in subjective feelings, it does not result in mental or psychomotor deterioration or increased susceptibility to social influence." Similarly Ecclestone, Gendreau and Knox in 1974 reported that for eight volunteers over a period of 10 days "solitary confinement was not more stressful than normal institutional life." But these outcomes may be accounted for by the short duration of stay in isolation and by the fact that prisoners who participated in these studies welcomed the opportunity to spend time away from the general prison population

Experimental studies with volunteers have reported relatively short-lived tolerances for isolation. Although such studies are not equivalent to enforced isolation in the prison context where prisoners are not free to end the experiment at any time, the findings serve to illustrate the powerful impact of isolation on human subjects. In a study aimed at measuring levels of tolerance to isolation, approximately two-thirds of the volunteers were able to remain in an isolated room for periods ranging from three to fourteen days (Zuckerman, 1964:255-276). In another, twenty volunteers were placed separately in a silent room, and asked to remain in it for as long as they could. The average quitting times were 29.24 hours for men and 48.70 hours for women. None of the participants endured the 'silent room' for longer than four days (Smith \& Lewty, 1959:342-345). Where the duration of isolation was unspecified, two hours were sufficient to generate confusion and the fear of becoming insane (Solomon et al, 1961).

Other studies have also demonstrated that an important element in the level of endurance of solitary confinement is prior knowledge of its duration. Uncertainty as to its duration "promotes a sense of helplessness. Finite sentences imposed for acknowledged acts seem less prone to inspire panic" (Toch, 1992:250). Another study concluded that uncertainty is a critical factor relating to the outcome of hostility and aggression (McCleery 1961:303). Knowing how long the experience is to last is therefore a clear mitigating factor available to those responsible for placing a prisoner in segregation. 


\subsection{Sequelae of isolation: the lasting effects of solitary confinement}

There are few longitudinal studies of the effects of solitary confinement and no follow-up studies of formerly isolated prisoners following their release from prison. Again, any long term effects are likely to be dependent on the individual, the type of confinement and its duration. One study of detainees held on remand in solitary confinement at the Western prison in Copenhagen, which examined them on the second to fourth day of their isolation and thereafter at monthly intervals, found a decrease in symptoms soon after transfer to the general population, indicating that "solitary confinement conditions are distressing and probably temporary, at least partially" (Andersen et al. 2003:174). The authors note, however, that "the finding that mental health condition improved when prisoners were moved from solitary confinement to non-solitary confinement indicates that solitary confinement imposes a condition that arguably could be avoided by abolishing it" (Ibid. at page 175).

Similarly, Grassian's (1983) study of prisoners held in solitary confinement at Walpole prison in Massachusetts, where the legal statute required that isolated prisoners be relieved from their status for at least 24 hours every 15 days, reported rapid diminution of symptoms during breaks in confinement.

However, other studies report sleep disturbances, nightmares, depression, anxiety, phobias, emotional dependence, confusion, impaired memory and concentration (Hocking, 1970) long after release from isolated environments. These symptoms are similar to those experienced by prisoners in isolation and may imply a degree of irreversibility. But the lasting effects of solitary confinement are perhaps most evident in social settings and with interpersonal relationships:

Although many of the acute symptoms suffered by inmates are likely to subside upon termination of solitary confinement many [prisoners], including some who did not become overtly psychiatrically ill during their confinement in solitary, will likely suffer permanent harm... this harm is most commonly manifested by a continued intolerance to social interaction, a handicap which often prevents the inmate from successfully readjusting to ... general population prison and often severely impairs the inmate's capacity to reintegrate into the broader society upon release from imprisonment (Grassian, 2006:332).

Former prisoners who have spent prolonged periods in solitary confinement have testified to experiencing difficulties in social situations long after their release:

I mean there are still times where I may go to the walk-in and after the movie's over and, you know, it's like I've been in the dark and all of the sudden the light comes on and boom all these millions of people around me, I'm like, you know, looking around like, okay, okay, who's gonna hit me, what's gonna happen ... I mean, you feel real uncomfortable and then all of the sudden you start shaking, you know, you feel your heart beat and then you realise, wait a minute, I'm at a theatre, what am I tripping on? There ain't nobody out here all crazy. I'm not in prison. It gets real uncomfortable when I'm around a big crowd. Like sometimes even going to the grocery store I feel uncomfortable, you know, when people look at me, and I'm wondering, you know, wow, what are they looking at? [Former prisoner, US. Cited in Shalev, forthcoming].

My character and personality have undergone many negative changes and I am now a very paranoid and suspicious person. The paranoia has become so extensive that I find it impossible to trust anyone anymore and I have developed a tendency to hate people for no apparent reason (Wakefield, 1980:30). 
Unable to regain the necessary social skills for leading a 'normal' life, some may continue to live in relative social isolation after their release. In this sense, solitary confinement operates against one of the main purposes of the prison which is to rehabilitate offenders and facilitate their reintegration into society.

\subsection{Concluding remarks about the effects of solitary confinement}

There are problems in drawing general conclusions from studies of particular prisoners and from experimental research with volunteers. Studies carried out with prisoners in the context of lawsuits being brought by the prisoner against the authorities raise questions about the partiality of the findings, as do studies carried out by medical professionals employed by the authorities responsible for the confinement. Getting access to prisoners in real life segregation for research purposes raises both practical difficulties and ethical concerns. There is also a clear lack of equivalence between the experience of solitary confinement in real life prisons and within the context of time-bounded experiments. The role of pre-existing mental health problems is also a significant compounding variable.

Nevertheless, there is a large and growing body of literature that demonstrates the harmful impact of isolation, particularly when used punitively, without clear time limits, for periods that are longer than four weeks and for people with prior mental health problems and poor social adjustment.

\section{Key points}

- There is unequivocal evidence, dating back to the $19^{\text {th }}$ century, demonstrating the negative health effects of solitary confinement.

- The extent of psychological and physiological damage of solitary confinement will depend on the individual prisoner, his background, the context of placement in isolation, its duration, conditions of confinement and degree of mitigation.

- Uncertainty about the expected duration of solitary confinement is likely to increase its adverse effects.

- While some of the health effects of solitary confinement will subside upon its termination, others may persist.

- For these reasons, the use of solitary confinement should be reserved for extreme cases, for as short time as possible, but usually no more than a matter of days.

- The misuse of the psychological and physiological effects of solitary confinement as part of an interrogation process may amount to cruel, inhuman or degrading treatment or punishment and even to torture, and should be prohibited in all circumstances. 
Notes

17 This chapter was co-authored with Monica Lloyd, Forensic Psychologist, formerly of the Chief Inspector of Prisons (HMCIP) office, and Jonathan Beynon, MD, Medical Co-ordinator for Health in Detention, International Committee of the Red Cross. The points of view expressed here represent the personal opinions of the authors, and do not necessarily represent the position of their organisations.

18 Reyes, H. The worst scars are in the mind: psychological torture, International Review of the Red Cross, Volume 89 No. 867, September 2007 pp 591-617. See also: Human Rights Watch report: Locked Up Alone: Detention Conditions and Mental Health at Guantanamo, June 2008; Physicians for Human Rights (PHR): Break them down: systematic use of psychological torture by US forces. Physicians for Human Rights, USA, 2005.

19 Principle 7 United Nations Basic Principles for the Treatment of Prisoners, adopted and proclaimed by General Assembly resolution 45/111 of 14 December 1990

20 This chapter is only intended as a brief and selective review of the literature. The studies examined in this review vary greatly in scope, location, context, factors examined and methodology. For a comprehensive review of the literature on the health effects of solitary confinement and a discussion of methodological issues see ScharffSmith (2006).

21 With the exception of Suedfeld \& Roy (1975) who suggested that short-term, non-punitive solitary confinement of volunteer participants may have beneficial effects (though these are not elaborated).

22 Reported in the Canadian Medical Journal 1977:408-416

23 Researchers reported emotional disturbances, disturbances in comprehension and ability to think, infantile regressive changes and difficulty in making social contacts, as well as sleep disturbances, headaches and severe digestive problems (cited in Amnesty International, 1980).

24 The authors note that many of the prisoners in both samples suffered prior mental health problems.

25 As Toch (1992:152) noted "personal breakdown in isolation does not square with manly self-images and reputations", so prisoners may find it easier to refer to others 'losing it'.

26 The symptoms listed in this section have been consistently reported by the studies discussed above. For a more detailed review of research findings see, Grassian \& Friedman (1986); Grassian (2006); Haney \& Lynch (1997); Haney (2003); Scharff-Smith (2006).

27 Mottram, P. 2007. HMP Liverpool, Styal and Hindley Study Report, University of Liverpool

28 "Health, which is a state of complete physical, mental and social wellbeing, and not merely the absence of disease or infirmity, is a fundamental human right ..."World Health Organisation, Declaration of Alma-Ata, 1978.

29 'Meaningful' is emphasised because it cannot be argued that regular contact with custodial staff whilst being fed, restrained and escorted constitutes meaningful contact.

30 See Mead (1934). For a review of social learning theories and their application in situations of social isolation see Haney \& Lynch 1997:503-506

31 A prisoner in Florida's Supermax, cited in the Campaign to Stop Control Units Report, 1997

32 See Sutherland \& Cressey (1955); Sykes (1958); Goffman (1961); McCleery (1961). See also Cohen \& Taylor's ([1972] 1981) study of prisoners in Durham prison's maximum-security wing in the late 1960s and Toch's (1992) study of prisoners' reactions to the "psychological strain of imprisonment". 


\section{The decision to place prisoners and detainees in solitary confinement}

The extreme nature of solitary confinement and its potentially harmful effects on prisoners' physical and mental wellbeing require prison authorities to be particularly cautious in imposing it, even for short periods of time. By extension, long-term prison regimes based entirely on solitary confinement run contrary to two of the primary goals of imprisonment, namely rehabilitation and social reintegration. This chapter examines the different uses of solitary confinement and some of the human rights provisions and recommendations that apply to them. Where current human rights standards and provisions are lacking, it seeks to explore how they may be developed and strengthened.

\subsection{When and why are prisoners and detainees placed in solitary confinement?}

Where prisoners and detainees are held in solitary confinement, whether in an especially designed free-standing isolation unit or in a designated segregation wing in a general population prison, this is typically on one of the following official grounds:

Punishment: punitive segregation is used as a form of punishment for prisoners' misconduct whilst in custody, and is typically imposed for a set, limited period of time, following some form of a disciplinary hearing within the prison. Segregation is considered as the most severe form of punishment for the most serious prison offences. Cell fittings in punitive segregation units are often minimal, and prisoners are allowed fewer provisions and personal belongings than those afforded to prisoners in 'normal location'. Prisoners held in punitive isolation typically only leave their cell for a one-hour period of solitary exercise a day, but in some jurisdictions, exercise as well as access to family visits, are restricted even further. Legislation in some jurisdictions also permits courts to impose periods of solitary confinement as a part of the sentence for certain crimes. In Peru, for example, under the rule of its former president, Alberto Fujimori, those convicted of crimes against the State were automatically placed in solitary confinement for the first year of their imprisonment. In Pakistan, the Penal Code allows for convicted prisoners to be sentenced by the court for up to three months in solitary confinement at the beginning of their sentence (Pakistan Penal Code, Act XLV of 1860).

Protection: protective segregation is used for holding vulnerable prisoners separately from the general prison population for their own protection, either at the prisoner's request or at the discretion of staff. Vulnerable prisoners may include, for example, sex offenders, police informants, 
former police or prison officers, debtors, prisoners at risk of self harm and those who might be harmed by other prisoners. In some jurisdictions these prisoners are allowed to associate with each other, whilst in others they are held in regimes of strict solitary confinement, identical to those in punitive segregation, for the duration of their prison sentence.

Prison management: managerial or administrative segregation is used as an internal tool for isolating prisoners variously defined as potentially dangerous, disruptive or otherwise posing a management problem, for example gang members. The rationale is that isolating such prisoners will reduce incidents of violence across the prison system and maintain prison order and discipline. This form of solitary confinement is usually imposed through an internal process governed by administrative rules. In some jurisdictions, prisoners are offered structured regimes starting with strict solitary confinement followed by gradually improved provisions and opportunities to engage with other prisoners, whilst in others, prisoners will be held in strict separation for the duration of their sentence. Where small group isolation is used, prisoners are held in single cells but allowed to associate with one to five other prisoners at designated times, usually during exercise periods.

National security: protecting the public and/or national security is, and has historically been, used as a justification for placing those suspected or convicted of politically motivated crimes and of senior membership of major organised criminal gangs in solitary confinement. The rationale is to prevent the prisoner from contact with 'terrorist' or 'subversive' groups or organised crime gangs outside the prison, or to prevent the dissemination of State secrets. Convicted prisoners isolated on grounds of national security will typically spend their prison sentence in strict solitary confinement.

Pre-charge and pre-trial investigation: suspects may be held in isolation without being charged whilst their interrogation is ongoing. In most jurisdictions such pre-charge detention is limited by law to a few hours or a few days, but some jurisdictions now have provisions for lengthier periods. In the UK, for example, terror suspects may be detained without any charge being brought against them for up to 28 days and, subject to a Bill introduced by the Government being enacted in its present form, this period may be extended to 42 days. Noting that the current provision of 28 days is already controversial, critics have called for this proposal to be scrapped. Pre-trial detainees, particularly those charged with crimes against the State, are also often isolated during the investigation or interrogation process. In some countries, most notably in Scandinavia, criminal suspects are also sometimes isolated pending investigation. The rationale in such cases is to prevent the detainee from compromising the investigation. In some cases detainees are isolated without access to legal counsel. This form of detention, called 'incommunicado', may be illegal under international law and is subject to special provisions ${ }^{33}$.

Lack of other institutional solutions: prisoners are also sometimes held in solitary confinement because there are no appropriate alternatives available for housing them. For example, mentally ill prisoners may be isolated because there are no available secure hospital beds for them. These prisoners may not necessarily pose a danger to others or to themselves, but they are vulnerable to abuse and their behaviour may disturb or unsettle other prisoners and prison staff. Prisoners may also be segregated due to prison overcrowding whilst waiting for space to become available in a setting appropriate to their security classification. 
In countries which still use the death penalty, and in those where it was only recently abolished, Death Row prisoners are also typically held in strict solitary confinement. Finally, prisoners may also be held in de-facto solitary confinement - sometimes remaining locked up in single occupancy cells due, for example, to staff shortages. To illustrate, in a recent report from the Chief Inspector of Prisons in England and Wales, 30\% of prisoners surveyed in local prisons in 2006/7 (some of whom were held in single cells) claimed that they were unlocked for less than two hours a day (HMCIP Thematic Report, Time out of Cell, 6 June 2008).

\section{Case study: Solitary confinement in England \& Wales}

Prisoners may be held in solitary confinement for periods of 22-24 hours a day in the following circumstances:

- In police custody, where they will invariably be held in a single cell. Most police detainees are released within less than 24 hours, but some may be held longer for questioning. Authority for this has to be granted from a senior police officer at nine hourly intervals up to 72 hours, at which point authority for continued detention has to be sought from a court. Those suspected of terrorism may be held in police custody for up to 28 days.

- If they are placed in segregation overnight for adjudication the following day (in which case their confinement may not exceed 24 hours).

- If they are awarded cellular confinement as a punishment, in which case this will last no more than 14 days in the case of young prisoners or 28 days in the case of adult prisoners.

- If they are placed in segregation to preserve good order or discipline (GOOD) or for their own protection (OP), in which case the period of time is open-ended. In these circumstances prisoners are subject to a local review of their confinement after the first 72 hours and weekly thereafter.

- If they are placed in the Close Supervision System (CSC) within a restricted regime, in which case they are provided with in-cell activities and a high level of staff engagement, and are subject to local monitoring and ongoing case management from the CSC selection committee within the High Security Directorate.

- When a CSC prisoner is transferred to a segregation unit in a high security prison and held in a designated CSC cell or high control cell* for a period of time-out, in which case they are subject to ongoing case management by the CSC selection committee within the High Security Directorate, but in practice to little local monitoring.

- When a prisoner with mental health problems is held in a single cell within the prison hospital under the care of health care staff.

*A high control cells are equipped with a feeding hatch in the cell door which allow for food and other provisions to be delivered without unlocking the prisoner at all. 


\subsection{Placement in solitary confinement: procedural safeguards, and special provisions and recommendations regarding the isolation of specific categories of prisoners}

As solitary confinement is a harsh measure with potentially harmful consequences for the prisoner involved, the decision to isolate a prisoner, be it as short-term punishment, for longer term management or for his own protection, must not be taken lightly or in an arbitrary manner. Good practice dictates that it must always be taken by a competent body, in accordance with the law and in adherence with the requirements of due process. The authority making the decision must justify its decision in writing, and be accountable for it. This authority should not the prison doctor, nor should the doctor certify the prisoner 'fit for isolation' (this issue is discussed further in some detail in Chapter Five). Another important safeguard where solitary confinement is imposed is to ensure that the decision to segregate a prisoner, or to continue his segregation, is substantially and regularly reviewed by an independent body, and that the prisoner has a right to appeal against the decision.

Such reviews should always be based on the continuous assessment of the individual prisoner by staff specially trained to carry out such assessment. Moreover, prisoners should as far as possible be kept fully informed of the reasons for their placement and, if necessary, its renewal; this will inter alia enable them to make effective use of avenues for challenging that measure (CPT 11th General Report, CPT/Inf (2001) 16, section 32).

\section{Review hearings: good practice example}

At Woodhill prison's (UK) Close Supervision Centre, where some of those considered to be amongst the most challenging prisoners in the prison system are held in solitary confinement, prisoners' placement is reviewed monthly, and prisoners' legal representatives are invited to attend their clients' review hearings.

The general procedural requirements and guarantees outlined above apply to the decision to place a prisoner in solitary confinement, regardless of the reason for his placement. In addition, some specific issues arise in relation to detainees and particular categories of prisoners who are placed in solitary confinement.

\section{Punitive segregation}

Punitive or disciplinary segregation is the most serious punishment which can be imposed on prisoners, and as such should be reserved for the most serious prison offences and be proportional to them. It must only be imposed as last resort and for as short a time as possible, lasting days rather than weeks or months.

Rule 30 of the UN Standard Minimum Rules for the Treatment of Prisoners (SMR) stipulates that: 
(2) No prisoner shall be punished unless he has been informed of the offence alleged against him and given a proper opportunity of presenting his defence. The competent authority shall conduct a thorough examination of the case.

Article 6 of the ECHR, which guarantees the right to a fair trial, also elaborates on some of the necessary safeguards:

1. In the determination of his civil rights and obligations or of any criminal charge against him, everyone is entitled to a fair and public hearing within a reasonable time by an independent and impartial tribunal established by law ...

3. Everyone charged with a criminal offence has the following minimum rights:

- to be informed promptly, in a language which he understands and in detail, of the nature and cause of the accusations against him;

- to have adequate time and facilities for the preparation of his defence;

- to defend himself in person or through legal assistance ... ;

- to examine ... witnesses against him ...;

- to have the free assistance of an interpreter if he cannot understand or speak the language used in court.

It has been established that these protections also apply to prison adjudication proceedings, particularly when a harsh penalty is imposed on the prisoner ${ }^{34}$.

\section{Pre-trial and pre-charge detainees}

The isolation of those who have not yet been convicted of any crime is particularly problematic, as it inflicts punitive and potentially harmful conditions on people who are innocent until proven guilty, and serves to coerce them.

Typically, in addition to being held in isolation from others, pre-trial detainees are subjected to further restrictions on visits and communications with the outside world. In Denmark and Norway, for example, remanded detainees may be held in solitary confinement for up to three months (or indefinitely, if the crime they are charged with will result in a prison term of more than six years if they are found guilty), allowed only supervised weekly visits lasting 30 minutes, prohibited from making telephone calls and may have their communications restricted or withheld. Such practices have been the subject of ongoing concern and criticism by international and regional monitoring bodies. The UN Human Rights Committee, for example, called on the government of Denmark to "reconsider the practice of solitary confinement so as to ensure that it was imposed only in cases of urgent need... except in exceptional circumstances, solitary confinement should be abolished, especially for pre-trial detainees... ${ }^{\prime \prime 35}$. 
Over time, through its visits to places of detention in Europe, the Committee for the Prevention of Torture has developed the following safeguards concerning the isolation of pre-trial detainees ${ }^{36}$ :

- Solitary confinement of pre-trial detainees should only be resorted to in exceptional circumstances, should be strictly limited to the requirements of the case, and should be proportional to the needs of the investigation;

- Restrictions should be authorised by a court;

- Detainees should have an effective right of appeal to a court or another independent body;

- Detainees should have access to a doctor whose written report should be forwarded to the competent authorities;

- Detainees should be offered purposeful activities in addition to outside exercise and guaranteed appropriate human contact.

These safeguards should be followed as a minimum in all cases. Isolating pre-trial detainees may also pressurise them to provide confessions in order to ease their conditions of confinement. The CPT has reported that in Denmark, for example, it was 'not unusual' for confessions to be immediately followed by a discontinuation of solitary confinement regimes ${ }^{37}$. This amounts to a form of coercion which, as stated in the introduction, should be prohibited.

The use of solitary confinement for those who have not yet been charged with any offence must be strictly limited by law and must only be used in exceptional circumstances, with judicial oversight, for as short a time as possible, and never for more than a matter of days. The misuse of solitary confinement in secret detention centres, particularly those linked with the so-called 'war on terror' as a means of coercing or 'softening up' detainees for the purpose of interrogation should be prohibited, as the deliberate infliction of mental and physical suffering for such purposes amounts to cruel, inhuman or degrading treatment and even torture.

\section{The mentally ill}

There is consensus amongst observers, experts and, increasingly, the courts, that the mentally ill and those at risk of self harm should not be held in solitary confinement - "The already mentally ill, as well as persons with borderline personality disorders, brain damage or mental retardation, impulse-ridden personalities, or a history of prior psychiatric problems or chronic depression ... For these inmates, placing them in [isolation] is the mental equivalent of putting an asthmatic in a place with little air to breath" (Madrid v. Gomez judgement, 1995). Yet, reports indicate that segregation is widely used to manage mentally ill prisoners, and that mentally ill prisoners are overrepresented in segregation units ${ }^{38}$.

The particular vulnerability of mentally ill prisoners means that prison authorities must be especially vigilant in their treatment. The Inter-American Court on Human Rights has stated that "... when the person kept in isolation in a penitentiary institution has a mental disability, this could involve an even more serious violation of the State's obligation to protect the physical, mental and moral integrity of persons held under its custody ${ }^{\prime 39}$. Thus, those suffering from mental illness must not be placed in solitary confinement and under no circumstances should the use of solitary confinement serve as a substitute for appropriate mental health care. 


\section{Challenging, dangerous, or disruptive prisoners}

As noted above, in some jurisdictions prisoners who are classified as dangerous or chronically disruptive are placed in prolonged solitary confinement as a prison management tool. The practice of "isolating risk", as one commentator termed it (Riveland 1999), is widely criticised. Supermax prisons in the United States, for example, have been criticised by the courts, the UN Human Rights Committee, the Committee Against Torture and the UN Special Rapporteur on Torture. All have stated that conditions of confinement in these prisons may amount to cruel, inhuman or degrading treatment in violation of international human rights law. Both the European Court of Human Rights and the Committee for the Prevention of Torture have expressed similar concerns about the 'special security' regimes imposed on prisoners in a number of European states. Referring to isolation at the Extra Security Institution (EBI) in the Netherlands, the CPT has stated that "to subject prisoners classified as dangerous to such measures could well render them more dangerous still" (CPT re Netherlands, 1998, para.69), and the ECtHR has stated on a number of occasions that it shares these concerns (for example, Mathew v. the Netherlands, 2005).

Addressing the use of 'reinforced security' units for holding dangerous prisoners, the Council of Europe's Committee of Ministers called on the Governments of Member States ${ }^{40}$ :

1. To apply, as far as possible, ordinary prison regulations to dangerous prisoners;

2. To apply security measures only to the extent to which they are necessarily required;

3. To apply security measures in a way respectful of human dignity and rights;

4. To ensure that security measures take into account the varying requirements of different kinds of dangerousness;

5. To counteract, to the extent feasible, the possible adverse effects of reinforced security conditions;

6. To devote all necessary attention to the health problems which might result from reinforced security;

7. To provide education, vocational training, work and leisure time occupations and other activities to the extent that security permits;

8. To have a system for regular review to ensure that time spent in reinforced security custody and the level of security applied do not exceed what is required;

9. To ensure, when they exist, that reinforced security units have the appropriate number of places, staff and all necessary facilities;

10. To provide suitable training and information for all staff concerned with the custody and treatment of dangerous prisoners. 
It is also worth noting that studies suggest that solitary confinement is not an effective tool for managing those defined as 'problem' or 'difficult' prisoners and may even be counter-productive. A study of the 'incorrigible units' in North Carolina in the late 1950s, where prisoners were subjected to a regime of strict and prolonged solitary confinement, concluded that "the over-all impact of the incorrigible unit in penal practice probably is one that intensifies tendencies to criminal attitudes and behavior" (McCleery, 1961:306). Other studies identified isolation regimes as central factors leading to prison riots. One study of events leading to the 1980 riot in the New Mexico Penitentiary (USA), for example, attributed the riot directly to the strategy of isolating prisoner leaders, which led to the fragmentation of prisoner solidarity and in turn led to growing violence. A study of 'order and discipline' in prisons in England and Wales concluded that "to impose additional physical restrictions, especially of a severe character, will almost certainly lead to a legitimacy deficit; and that deficit may well in the end play itself out in enhanced violence" (Bottoms, 1999:263).

Similar findings emerge with regard to the isolation of gang members. One study found that the policy of placing gang members in solitary confinement in special security units in California led to an increase in gang activity, as "prison authorities' efforts to contain the spread of gangs led, unintentionally, to a vacuum within the prison population within which new prison groupings developed" (Hunt et al. 1993:403). Leadership struggles among these new groupings then resulted in gang related murders in general population prisons (Parenti, 1999:209). Data on prison violence before and after the introduction of special security (or 'supermax') units, similarly indicates that the isolation of prisoners classified as dangerous or disruptive did not result in a reduction of prison violence in general population prisons ${ }^{41}$.

In short, though solitary confinement may be a convenient tool for managing challenging prisoners in the short term, in the long term it is not effective, and may prove to be counter-productive. Further, as Chapter Two illustrated, prolonged solitary confinement may have very serious health consequences for the individual concerned and may also affect his chances of successful reintegration into society. Every effort should therefore be made to reverse the trend towards supermax prisons and similar regimes which are wholly based on solitary confinement. Where it is absolutely necessary to hold a handful of extremely dangerous prisoners in separation from others, there should be ongoing assessment of the need to keep them isolated, and they should be afforded increased in-cell provisions, access to programmes, opportunities for meaningful human contact and so on. 


\subsection{The human rights position and case law regarding the placement of prisoners in solitary confinement}

The potentially harmful effects of solitary confinement are recognised by human rights bodies, who view it as an undesirable prison practice which can only be justified in extreme cases ${ }^{42}$, must only be used for the shortest time possible ${ }^{43}$, and which, in certain circumstances, may be in violation of international law.

The Human Rights Committee has expressed the view that

"solitary confinement is a harsh penalty with serious psychological consequences and is justifiable only in case of urgent need; the use of solitary confinement other than in exceptional circumstances and for limited periods is inconsistent with article 10, paragraph 1, of the Covenant ${ }^{144}$ and may amount to acts prohibited by Article 7 (torture and cruel, inhuman or degrading treatment or punishment) ${ }^{45}$.

The UN Committee Against Torture (CAT) has been critical of practices involving prolonged solitary confinement and has stated that these may amount to treatment in violation of the prohibition against torture or inhuman treatment. For example, the CAT has expressed grave concerns regarding the strict and prolonged solitary confinement in supermax prisons in the United States (CAT, 2000); lack of time limits on placement in solitary confinement and the number of detainees isolated for more than ten years in Japan (CAT, 2007); and, the isolation of pre-trial detainees in Denmark and Norway (CAT, 2002).

A joint report issued by UN Rapporteurs on the situation of detainees held by US forces at Guantanamo Bay stated that "the general conditions of detention, in particular the uncertainty about the length of detention and prolonged solitary confinement, amount to inhuman treatment and to a violation of the right to health as well as a violation of the right of detainees under article 10 (1) of ICCPR to be treated with humanity and with respect for the inherent dignity of the human person" (Report to the UN Commission on Human Rights, 62 Session, 15/2/06, UN DOC E/CN.4/2006/120).

The European Committee for the Prevention of Torture (CPT) has taken the view that solitary confinement, for whichever reason, requires particular attention. In assessing any one case,

"the principle of proportionality requires that a balance be struck between the requirements of the case and the application of a solitary confinement-type regime, which is a step that can have very harmful consequences for the person concerned" ${ }^{\prime \prime 6}$. 
Grounds which were accepted by the European Court of Human Rights (ECtHR) as justifying solitary confinement include: the prisoner's extremely dangerous behaviour", the prisoner's "ability to manipulate situations and encourage other prisoners to acts of non-discipline ${ }^{\prime \prime 48}$ and the prisoner's safety". The "general situation regarding terrorist climate at the time" was also found to justify severe security measures, including solitary confinement ${ }^{50}$. Ten years later, in 1992, the Court somewhat narrowed this view when it stated that "the undeniable difficulties inherent in the fight against crime, particularly with regard to terrorism, cannot result in limits placed on the protection to be afforded in respect of the physical integrity of individuals ${ }^{\prime \prime 51}$. These protections are not dependent on the individual's conduct: "The Court is well aware of the immense difficulties faced by States in modern times in protecting their communities from terrorist violence. However, even in these circumstances, the Convention prohibits in absolute terms torture or inhuman or degrading treatment or punishment, irrespective of the victim's conduct"s2. In a more recent case, whilst the Court reaffirmed that the absolute prohibition against torture, inhuman or degrading treatment extends even to the "most difficult circumstances, including the fight against terrorism and organised crime", and that solitary confinement must never be imposed on prisoners indefinitely, it ruled that holding a man who, at the time, was "considered to be the most dangerous terrorist in the world" in solitary confinement for 8 years and two months did not constitute a breach of Article 3 of the ECHR ${ }^{53}$.

But the Court's willingness to accept that prolonged solitary confinement may be justified in exceptional cases, particularly those involving offences against the State, does not extend more generally. The placement of a prisoner in solitary confinement because he could not adapt to an ordinary prison setting was not accepted as sufficient grounds, and was found to constitute inhuman treatment in breach of Article $3^{54}$. A breach of Article 3 was also found where a regime of strict solitary confinement was imposed for more than three years on a former Death Row prisoner yet "the government have not invoked any particular security reasons ... and have not mentioned why it was not possible to revise the regime ${ }^{55 "}$ ".

Hence, while it is generally accepted that in the prison setting short-term solitary confinement may sometimes be necessary, its use is subjected to close scrutiny to ascertain whether it serves a legitimate purpose, and is absolutely necessary in any given case. Once it is established that the placement of a prisoner in solitary confinement has been undertaken in accordance with due process requirements and serves a legitimate purpose, the physical conditions and regime afforded to isolated prisoners are addressed. These are the subject of the following chapter. 


\section{Key points}

- The decision to place a prisoner in solitary confinement, for whatever reason, must always be made by a competent body and in accordance with due process requirements, including the right to appeal against the decision.

- When used as punishment for prison offences, solitary confinement must only be used as a last resort, and then for the shortest time possible, no more than a matter of days.

- Ensuring that the process through which prisoners are isolated is transparent and adheres to due process requirements not only ensures that the decision is carried out legally and professionally, but may also contribute to prisoners' perception of their placement as being legitimate and fair and, in turn, positively affect their behaviour.

- The use of prolonged solitary confinement for managing prisoners is rarely justified, and then only in the most extreme of cases.

- Solitary confinement is an undesirable tool for the long term management of challenging prisoners, and may be counter-productive.

- Those suffering from mental illness must not be placed in solitary confinement and under no circumstances should the use of solitary confinement serve as a substitute for appropriate mental health care.

- The use of solitary confinement for pre-charge and pre-trial detainees must be strictly limited by law, must only be used in exceptional circumstances, with judicial oversight, and for as short a time as possible, never for more than a matter of days.

- The use of solitary confinement as a means of coercing or 'softening up' detainees for the purpose of interrogation should be prohibited.

- Solitary confinement should never be imposed indefinitely and prisoners should know in advance its duration. 
Notes

33 Incommunicado detention involves the detainee being held without access to a lawyer, doctor and family members. The UN Special Rapporteur on Torture has proposed that this form of detention be declared illegal, as it is "the most important determining factor as to whether an individual is at risk of torture" and called on States to release all persons held incommunicado without delay (Report by the Special Rapporteur on the question of torture and other cruel, inhuman or degrading treatment or punishment (1999) UN doc. A/54/426, par. 42; Same, 1995 Report UN doc. E/CN.4/1995/34, par. 926). Successive resolutions of the UN Commission on Human Rights have reiterated this stance and stated that prolonged incommunicado detention can in itself constitute a form of cruel, inhuman or degrading treatment (see for example Commission on Human Rights resolutions 1997/38, 1998/37 and 1999/32). The UN Human Rights Committee called on States to make provisions against incommunicado detention (General Comment 20), and in considering individual cases involving incommunicado detention for varying periods of time found a violation of Articles 10 and/or 7 of the ICCPR (in many cases the applicant's incommunicado detention was accompanied by other deprivations. See, for example: de Polay v. Peru (1997) Communication 577/1994; Mukong v. Cameroon (1994) Communication 458/1991; Gilboa v. Uruguay (1985) Communication 147/1983). The European Court of Human Rights (ECtHR) found a breach of Article 6 protections where detainees were held incommunicado for 24 hours in one case and 48 hours in another (Averil v. UK, ECHR 212, [2001] 31 EHRR 36; John Murray v. UK, ECHR 3, [1996] 22 EHRR 29). The Inter-American Court of Human Rights found a violation of the prohibition against torture, inhuman or degrading treatment where a detainee was held incommunicado for 36 days, and declared that this form of detention, in itself, may constitute a violation of human rights law (Castillo Petruzzi et al. v. Peru, Judgement of 30 May, 1999.).

34 Ezeh and Connors v. UK, Judgement of 9/10/2003, (violation of Article 6(3)); Whitfield and others v. UK., Judgement of 12/7/2005 (violation of Article 6(1) and 6(3)c .)

35 UN Human Rights Committee (2001) A/56/156, Session of 3/11/2000.

36 See CPT reports, particularly report re Denmark (1991 para.29; 1997; 2001); Norway (1994; 1996; 2006); Sweden (1995 paras.19-27).

37 CPT/Inf (2002) 18, at para.39.

38 In the UK, for example, see: Dora Rickford and Kimmett Edgar, Troubled Inside: Responding the Mental Health Needs of Men in Prison, Prison Reform Trust, 2005, in particular chapter 5, and HMCIP report, The Mental Health of Prisoners, A thematic review of the care and support of prisoners with mental health needs, October 2007.; In the US, see: The Commission on Safety and Abuse in America's Prisons: Confronting Confinement, June 2006. See also Prison Reform International (2003) Training Manual no. 1: Human Rights and Vulnerable Prisoners.

39 Victor Rosario Congo v. Ecuador, Case 11.427, Report No. 63/99, Inter-Am. C.H.R., OEA/Ser.L/V/II.95 Doc. 7 rev. at 475 (1998). April 13, 1999 para.58; See also ECtHR cases cited below

40 Recommendation concerning Custody and Treatment of Dangerous Prisoners (No. R (82) 17)

41 Shalev, S. (2007). 'The power to classify: avenues into a supermax prison' in: Downes, D., Rock, P., Chinkin, C. and Gearty, C. (Eds.) Crime, Social Control and Human Rights: From moral panics to states of denial, Devon: Willan Publishing, pp. 107-119. See also Briggs et al. (2003) 'The effects of supermaximum security prisons on aggregate levels of institutional violence', Criminology, Vol.41 (4) pp 1341-1376.

42 See for example the ECtHR judgements in Ensslin, Badder and Raspe v FRG , DR 14 (1978); Xv FRG, Application 6038/73 Coll. 44 (1973).

43 Mathew $v$ the Netherlands, Judgement of 29/9/2005 at Para. 199. See also CPT 2nd General Report CPT/Inf (92)3 par. 56

44 Human Rights Committee, Concluding Remarks on Denmark. 31/10/2000. CCPR/CO/70/DNK

45 General Comment 21/44, of 6 April, 1992.

46 CPT, 2nd General Report, 1992 par. 56.

47 Mv UK, application 9907/82 DR 35 (1983) 
$48 \quad$ X V UK, application 8324/78 unpublished

49 Xv UK, application 8241/78 unpublished

50 Krocher and Moller v Switzerland, DR 34 (1982) p 54.

51 Tomasi v France A 241-A,1992

52 Chahl v. The UK, Judgement of 15/11/96, para.79

53 Ramirez Sanchez v. France, application no. 59450/00, Judgment of 27.1.05. The Ramirez case is quite unusual. Not only was he a very 'high profile' prisoner, but his conditions of confinement were relatively comfortable, he had frequent contact with people from outside the prison, and was in apparent good physical and mental health. In reaching it decision, the Court relied heavily on these factors and on the fact that he was later removed from solitary confinement and placed in an ordinary prison wing.

54 Mathew $v$ the Netherlands, Judgement of 29.9.2005

55 lorgov v. Bulgaria (2004) ECHR 113 (2005) 40 EHRR 7, ECtHR 185 par. 84 


\section{$4 \mid$ Design, physical conditions and regime in solitary confinement units}

\subsection{Introduction}

The design layout and 'hardware' of a prison building- including building materials, colour schemes and surveillance mechanisms- have a great impact on the way in which the prison is managed, on its regime, on the daily experiences of prisoners and staff and on the relationship between them. The specific design features of any prison are determined by many factors including its age, size, construction and operating budgets, its mission statement and the prevailing penal policies and attitudes and managerial theories at the time. By extension, the design of segregation units varies greatly, not only between one State and another, but also within the same jurisdiction, affording prisoners different levels of interactions, sensory stimulation, comfort, privacy, and so on.

Although the architectural design of isolation units and cells varies between prisons and jurisdictions, they typically share some common features including: location in a separate or remote part of the prison; the absence of, small, or partially covered windows; sealed air quality; stark appearance and dull colours; toughened cardboard or other tamper proof furniture bolted to the floor; and, small and barren exercise cages or yards. These features constitute a claustrophobic and monotonous environment, which has health implications for both prisoners and, to some extent, staff who work in these units. Such health implications are made worse by the lack of opportunities for social, vocational and recreational activities which also characterise these units.

Newly built isolation units tend to adopt the 'small pod' design where cells are grouped together in small clusters (or 'pods') of 6-8 single cells, arranged around a centralised control room from which prisoners are supervised. These units are designed to increase surveillance and to enable prolonged solitary confinement and minimise contact between prisoners and staff. Cells are self contained with a toilet and a wash-basin. Other measures, such as feeding-slots built into cell-doors, are taken to ensure that most services can be provided to prisoners inside their cells, reducing prisoner movement in and outside the unit. Typically, physical conditions in the new, purpose built isolation units are better than those in segregation units in older prisons, which were not designed for prolonged solitary confinement. Conversely, since in the newer purpose-built units most prisoner services can be provided in the cell or at the cell-front, prisoners enjoy even less stimulation and opportunities for interaction than in older segregation units. In some of the newly built isolation units, cells are also soundproofed and/or do not have windows, further reducing sensory stimulation. 
The design of the prison is closely linked to its regime. Together they have great impact on prisoners' experience of the prison and their wellbeing. The section which follows examines international standards regarding prison conditions and regime, with a special emphasis on solitary confinement units.

\subsection{International standards regarding prison conditions and regime}

Human rights instruments form the guiding principles and minimum standards for the humane treatment of prisoners. The daily running of prisons is governed by national laws and prison rules which include detailed practical provisions, but they must in all cases conform to the overarching international human rights standards ensuring that prisoners are held in a humane manner in a sanitary and healthy environment. Indeed, monitoring bodies and the courts pay particular attention to the physical conditions in which prisoners are held and will be more inclined to find a violation of human rights law where these fall below the required minimum standards.

Having regard to the diversity in resources, laws and cultures of states, Article 2 of the UN Standard Minimum Rules (SMR) stipulates that standards should "serve to stimulate a constant endeavour to overcome practical difficulties in the way of their application, in the knowledge that they represent, as a whole, the minimum conditions which are accepted as suitable by the United Nations". In its General Comment 21, on the interpretation of what is meant by treating all persons deprived of liberty with "humanity and with respect for their inherent dignity" (ICCPR, Article 10), the UN Human Rights Committee made clear that such treatment is fundamental, and "cannot be dependent on the material resources available in the State party" (Human Rights Committee General Comment 21, Article 10 of the International Covenant on Civil and Political Rights (44th Session 1992)). In other words, these minimum requirements must be observed, "even if economic or budgetary considerations may make compliance with these obligations difficult"s6.

As their title implies, the Standard Minimum Rules (and other similar instruments) set out the baselevel minimum requirements for the operation of prisons globally. The standards examined below are generic and apply to all prisons and to all sections of the prison, but they take on a particular importance in solitary confinement units. Conditions which fall below these minimum standards may constitute cruel, inhuman or degrading treatment or punishment. Adherence to, or even improvement on, the standards discussed below still does not mean that solitary confinement necessarily becomes any less damaging. But ensuring humane conditions and access to meaningful human contact may help mitigate some of its harmful effects.

\section{A. Physical conditions}

As noted above, instruments such as the UN Standard Minimum Rules (SMR) and European Prison Rules (EPR) prescribe minimum standards of physical conditions in all places of confinement. These include: 


\section{Cells}

Rule 10 of the UN SMR stipulates that:

All accommodation provided for the use of prisoners and in particular all sleeping accommodation shall meet all requirements of health, due regard being paid to climatic conditions and particularly to cubic content of air, minimum floor space, lighting, heating and ventilation.

The European Prison Rules (2006 revisions) use similar language, adding the importance of privacy (Article 18.1). Article 18.3 of the EPR stipulates that specific minimum requirements shall be set in national law.

Cell size and fixtures are of particular importance where prisoners spend most of their day inside the cell in solitary confinement. While international instruments do not specify a minimum size for cells intended for solitary confinement, one can infer from judgements and reports what constitutes an acceptable standard. The European Committee for the Prevention of Torture (CPT) found that solitary confinement cells measuring 8 sq. m. (CPT re Germany, 1993) and 9 sq. m. (CPT re the Netherlands, 1993) to be of a'reasonable size' for single occupancy, and cells measuring 11 sq. m. to be of a 'good size' (CPT re Netherlands, 1998). The European Court of Human Rights judged a cell measuring 6.84 sq. m. to be 'sufficiently large' for single occupancy (Ramirez v. France, Judgement of $27 / 1 / 2005)$. Clearly, any cell should be large enough to allow sufficient area for sleeping, eating and studying, whilst keeping the lavatory area separate.

\section{Windows and light}

The use of dark cells as punishment is prohibited under international human rights law (SMR 31; EPR 62.3). International standards also require that in all places where prisoners live or work:

(a) The windows shall be large enough to enable the prisoners to read or work by natural light, and shall be so constructed that they can allow the entrance of fresh air whether or not there is artificial ventilation (SMR Rule 11a).

Windows are particularly important where prisoners spend most of their day alone in the cell. The existence of windows, or lack thereof, as well as access to natural light for prisoners held in solitary confinement, have been important factors in the assessment of prison conditions by human rights bodies and the courts, and can tip the balance between acceptable conditions and inhuman treatment. In addition to natural light, international instruments also require that:

Artificial light shall be provided sufficient for the prisoners to read or work without injury to eyesight (SMR Rule 11b)

Cell fittings should enable prisoners to control artificial light inside their cells. In no case should cell lights be left on continuously. 


\section{Sanitary fixtures and personal hygiene}

Articles 12 and 13 of the UN SMR stipulate that

12. The sanitary installations shall be adequate to enable every prisoner to comply with the needs of nature when necessary and in a clean and decent manner.

13. Adequate bathing and shower installations shall be provided so that every prisoner may be enabled and required to have a bath or shower, at a temperature suitable to the climate, as frequently as necessary for general hygiene according to season and geographical region, but at least once a week in a temperate climate.

The standard set by European Prison Rules is for prisoners to be allowed to shower daily if possible, and at least twice a week (EPR Rule 19.4). Cells used for solitary confinement should, at a minimum, have an in-cell lavatory and wash-basin installed, and where possible, also a shower. These should be situated in a far corner of the cell and screened-off to afford the prisoner privacy. Prisoners should be provided with water and the necessary toiletries to maintain personal cleanliness (SMR Rule 15; EPR Rule 19.6), and with cleaning materials to maintain the cleanliness of their cells. More generally, all areas used by prisoners including showers, exercise areas and corridors should be clean and well maintained.

\section{Other environmental features}

The monotonous and claustrophobic environment of segregation units can be improved by some additional design features including ${ }^{57}$ :

- Good ventilation and comfortable temperatures, ideally controlled by the prisoner

- Low noise levels

- 'Soft materials' for cell furnishings

- Colourful environment

- Privacy

- Alarm button

\section{Physical design and conditions: country examples}

The importance of good prison design and adequate physical provisions is perhaps best illustrated by examples of segregation units which fail to meet international standards. The selection below is drawn from reports on physical conditions in segregation units in various countries. 


\section{Physical conditions in segregation units: case studies}

The 'S' security cells in Staubing prison (Germany)

Once inside the cell with all the doors closed, prisoners could not hear any of the usual prison sounds. The cells were located at the intersection of the wings of a building and were reached through a door opening onto a corridor, which served as a form of antechamber and where the showers were also situated. Each corridor contained two cells. In principle, there were no guards in the corridors and the occupants of the cells had no opportunities for visual or other forms of sensory contact with other prisoners or prison officers [CPT report 1993, par. 74-75.]

\section{The isolation cells in Komotini prison (Greece)}

Were also not in a fit condition to hold prisoners... [cells were] hot and filthy, with a putrid smell; there was poor ventilation, no bed (only a dirty mattress on the ground), no wash basin (hands were washed in the toilet) and minimal access to natural light [CPT report 2006, par. 41].

The disciplinary cells at Sremska Mitrovica prison (Serbia)

Were equipped with only a wooden platform (with a mattress and bedding), a box for personal belongings, a sink and an Asian-type toilet ... access to natural light and artificial lighting were at best mediocre [CPT report 2006, par.133].

\section{Cells in Section 209 of Evin prison (Iran)}

Were placed in the basement ... Cells measured about one meter by two meters, with a ceiling height of about four meters. A light at the top of the cell is on twenty-four hours a day. Cells had a toilet and a sink. The floor was made of... chalk [and] the walls were all white. Some prisoners were granted twenty minutes per day in a caged outdoor area, but others never saw the open air... [Human Rights Watch, "Like the Dead in Their Coffins" Torture, Detention and the Crushing of Dissent in Iran; June 2004, Vol. 16, No.2 (E)

\section{B. Prison regime}

While it is generally accepted by human rights and monitoring bodies that certain restrictions may be unavoidable in segregation units where solitary confinement is imposed as a short-term disciplinary punishment, prison authorities are nonetheless required to provide prisoners with minimal regime provisions, as prescribed in international instruments. Where prisoners are held in longer term solitary confinement, international bodies make it clear that they must be afforded access to prison programmes and meaningful human contact. The minimal regime provisions prescribed by international instruments include some of the following:

\section{Access to outdoor exercise}

27.1 Every prisoner shall be provided with the opportunity of at least one hour of exercise every day in the open air, if the weather permits.

27.2 When the weather is inclement alternative arrangements shall be made to allow prisoners to exercise. (European Prison Rules (2006 rev.); SMR Rule 21(1)) 
The requirement for prisoners to have at least one hour of open-air exercise daily is generally accepted as an absolute minimum (CPT/Inf(93)15 at para.95). Where possible, prisoners should be allowed to associate with each other during recreation time (see also EPR 27.7). For prisoners held in solitary confinement, the exercise period is the only opportunity they have to get fresh air and a glimpse of the world outside their cells. This requirement is therefore of particular importance and should be strictly adhered to with a view to extending recreation times and enabling prisoners to exercise together. The lack of opportunity for outdoor exercise combined with the lack of access to natural light was found by the European Court of Human Rights to amount to degrading treatment in violation of Article 3 of the ECHR ${ }^{58}$.

Designated exercise yards in segregation and special high security units often comprise a small and barren concrete enclosure (see various CPT Country Reports). In some jurisdictions the area is covered with metal mesh obstructing the view of the sky. This should be avoided. Exercise yards should be of sufficient size to enable prisoners to exert themselves and, so far as possible, should be equipped with appropriate equipment. Efforts should also be made to modify the bleakness of exercise yards through, for example, painting the area or planting greenery.

\section{Exercise yards: good practice example}

Exercise yards at the Extra Security Unit (EBI) in Vught prison (the Netherlands) were "large enough for prisoners to exert themselves physically" and had a 'running strip' for prisoners who "wished to engage in more strenuous physical activities". Exercise could take place with between one to three other prisoners. Prisoners also had access to a large and well equipped gymnasium. [CPT Report, 1998, CPT/Inf(98)15.]

\section{Access to programmes}

Provisions shall be made for the further education of all prisoners capable of profiting thereby ... the education of illiterates and young prisoners shall be compulsory and special attention shall be paid to it by the administration (SMR Rule 77; EPR (2006 Rev) Rule 28)

Recreational and cultural activities shall be provided in all institutions for the benefit of the mental and physical health of prisoners (SMR Rule 78)

All prisoners shall have the right to take part in cultural activities and education aimed at the full development of the human personality (Basic Principles for the Treatment of Prisoners, Principle 6)

Programme provision in prisons has many obvious advantages for prisoners' wellbeing and personal development as well as for their prospects of successful reintegration upon release. Research also strongly suggests that access to programmes in prison positively affects behaviour, whereas the lack of things to do may result in increased violent behaviour. A literature review of over ninety studies of the impact of prison programmes concluded that: 
"Research shows a fair amount of support for the hypothesis that adult academic and vocational correctional education programs lead to fewer disciplinary violations during incarceration, reductions in recidivism, increases in employment opportunities, and to an increase in participation in education upon release" (Gaes et al. 1999:411).

Prisoners held in disciplinary segregation for a short period of time may excluded, as part of their punishment, from participation in prison programmes. However, programme provision is crucial for prisoners who are isolated for longer periods of time, as they enjoy little or no social contact, experience substantially reduced sensory stimulation, and have very few means to occupy themselves inside their solitary cells. As Chapter Two demonstrated, these factors have negative health effects and may also lead to behavioural problems. To counteract such effects, research suggests that it is crucial for prisoners to have access to an adequate programme of activities in custody, particularly in high security prisons: "the greater the security of an institution, the more intense must be its activity program. Maximum prison lock-up without an appropriate activity program is detrimental to the inmate's health and his rehabilitative prognosis" (Scott \& Gendreau, 1969:341). CPT Standards elaborate:

"The existence of a satisfactory programme of activities is just as important - if not more so - in a high security unit than on normal location. It can do much to counter the deleterious effects upon a prisoner's personality of living in the bubble-like atmosphere of such a unit. The activities provided should be as diverse as possible (education, sport, work of vocational value, etc.). As regards, in particular, work activities, it is clear that security considerations may preclude many types of work which are found on normal prison location. Nevertheless, this should not mean that only work of a tedious nature is provided for prisoners" (CPT Standards, CPT/Inf/E(2002)1 Rev. 2006, par.32).

Ideally, programmes should be provided outside the cell and in association with others. Where this is not feasible, prisoners should, as a minimum, be provided with in-cell or at-cell-door programme delivery.

\section{Access to activities: good practice example}

The Close Supervision Centre (CSC) at Whitemoor prison (UK) has a communal area with table tennis and pool tables, a classroom equipped with a computer, a trolley of books and a stock of board games, and a workshop. It also has a well equipped fitness suite with free weights and an outside exercise yard which contained a greenhouse and a secure garden. [HMCIP, Extreme Custody, June 2006]

\section{Access to meaningful human contact within the prison}

It is crucial for isolated prisoners, particularly those isolated for longer periods, to have regular and meaningful human contact. The potential health effects of social isolation have been discussed in detail in Chapter Two but here it should be noted that every effort should be made to ensure that the prisoner has some degree of interaction with other human beings. This may mean, for example, allowing some association between prisoners during meal or recreation times, encouraging contact between the prisoner and educational, health and religious staff, allowing visits by 'prison visitors' 
and so on. Informal interactions with custodial staff should also be encouraged. Monitoring bodies and the courts pay particular attention to the level and quality of human contact afforded to isolated prisoners and will be more inclined to find a violation of human rights law where these are lacking.

\section{Contact with the outside world}

Human rights law emphasises the importance of enabling prisoners to maintain contact with the outside world. This requirement covers visits by family and friends, access to written and broadcast media and various forms of communication including letters and the telephone. Where prisoners are held in solitary confinement and enjoy little human interaction and few social contacts, these requirements become all the more important. Contacts with family, friends, and the community are not only important factors for prisoners' wellbeing, but have also been shown to be important factors in positively influencing prisoners' behaviour and improving their chances of successful reintegration upon release from prison ${ }^{59}$

\section{Family contacts}

Article 17 of the International Covenant on Civil and Political Rights (ICCPR) stipulates that

No one shall be subjected to arbitrary or unlawful interference with his privacy, family, home or correspondence...

The right to family life is also protected under Article 11 of the American Convention on Human Rights and Article 8 of the European Convention on Human Rights. It has been established that, notwithstanding limitations inherent in prison life, prisoners retain the right to family life and prison authorities have a duty to assist them in maintaining close family contacts (Messina (No.2) v. Italy, 2000).

Prisoners' right to respect for their family life through visits and communications is further established in several international instruments:

Prisoners shall be allowed under necessary supervision to communicate with their family and reputable friends at regular intervals, both by correspondence and by receiving visits (SMR Rule 37. See also: SMR Rule 79; Principle 19 of the Body of Principles for the Protection of All Persons Under any Form of Detention or Imprisonment; EPR (2006 Rev) Rule 24).

To encourage family ties, where possible, prisoners should be housed in a prison close to their home (Body of Principles, Principle 20). Visits should take place in specially designated areas which should be appropriately furnished, clean and well maintained. It is good practice to allow for contact visits (i.e. not held through a glass partition) between the prisoner and their visitor(s), particularly when the visitor is a child. Visitors should be treated with respect and must not be subjected to unnecessary security procedures. 


\section{Access to written and broadcast media}

Prisoners shall be kept informed regularly of ... items of news by reading newspapers... by hearing wireless transmissions ... or by any similar means (SMR Rule 39)

This requirement, again, is particularly important when the prisoner is held in prolonged solitary confinement with little access to the outside world. Knowledge of, and interest in, current and community affairs will not only assist the prisoner's eventual transition back to life as a free member of society, but may also have a positive effect on his mental wellbeing during his time in isolation. For these reasons, it is also recommended that, so far as possible, prisoners held in solitary confinement, particularly for prolonged periods, have television sets and radios in their cells.

\section{Impoverished regimes: country examples}

The main component of solitary confinement regimes, of course, is that the detainee or prisoner is held alone in their cell for up to 24 hours a day. The specific provisions which prisoners are entitled to whilst in segregation, and the degree and level of contact that they have with the outside world, however, varies from one jurisdiction to another. As noted earlier, in addition to 'regular' segregation units, some jurisdictions now also operate regimes specifically designed to place further restrictions on certain categories of prisoners who are in solitary confinement. Some examples of such regimes are set out below.

\section{Impoverished solitary confinement regimes: case studies}

\section{Italy}

Prisoners may be placed in solitary confinement for the duration of their sentence under a 'special regime' for reasons of public order and security, in particular offences relating to Mafia activities. They are held in single cells and allowed to mingle with between three to five others during exercise period. Some of the additional measures which may be applied under this regime, at the discretion of prison staff, include:

- A ban on visits by persons other than family members, a cohabitant or a lawyer;

- A maximum of one family visit lasting one hour each month;

- No access to a telephone or a maximum of one telephone call per month;

- Censorship of all correspondence except for privileged correspondence;

- No more than two hours per day to be spent outdoors;

- No extra visits allowed for good conduct;

- No more than two parcels per month;

- No sums of money to be received from outside prison or sent out;

- No handicrafts;

- No conversation or correspondence with other prisoners. 


\section{The Netherlands}

Prisoners who are considered extremely likely to attempt to escape from prison and who, if they succeed, pose an unacceptable risk to society in terms of committing further serious violent crimes or in terms of severe disturbance of public order, may be placed at the extra-security units (EBI and (T)EBI) at Vaught prison, which have a total capacity of 35 cells. The regime and security arrangements at the units include some of the following:

- Two screened telephone calls of up to 10 minutes a week and screening of all non-privileged correspondence;

- Closed, pre-arranged visits with approved visitors (one weekly visit of up to an hour);

- One monthly contact visit with immediate family/spouse lasting an hour (physical contact is limited to a handshake upon arrival and departure; guards remain in close proximity throughout the visit; visitors are subjected to a search ('frisking') prior to visit)

- No educational activities and limited in-cell work opportunities;

- Staff are separated from prisoners by a glass partition; only one prisoner at a time may come into contact with staff, and at least two staff members must be present; on such occasions the prisoner must be handcuffed;

- One hour a day of outdoor exercise with between one and three other prisoners;

- Up to six hours weekly of 'group activities' with no more than three others;

- Weekly cell searches;

- Weekly strip searches.

\section{United States}

Prisoners who are classified as gang members or have been found guilty of a 'serious rule violation' in prison may be held in solitary confinement in the Security Housing Unit (SHU) at Pelican Bay State Prison (California) for periods ranging from two to five years in the case of rule violators and indefinitely in the case of gang members. Once at the SHU, which has capacity of 1056 cells, they spend 23 to 24 hours a day inside their cell and have access to the following:

- Solitary exercise in a small and barren exercise yard for one hour four times weekly;

- A 15 minute long shower in a single shower-cell three times weekly;

- One quarter of the monthly canteen allowance;

- No access to recreational or vocational activities;

- Telephone calls on an emergency basis only, as determined by staff;

- Two 2 hour long no-contact family visits on weekends once a month;

- One annual package, not exceeding 30 pounds in weight;

- One-off special purchase of one television or one radio/television unit;

- Up to ten items of reading materials (magazines and books);

- No hobby or craft materials. 
As these examples demonstrate, although provisions for prisoners who are held in solitary confinement regimes vary between States, such regimes typically involve further restrictions and security measures in addition to the physical segregation of prisoners from the general prison population. It is difficult to see what legitimate penal purpose is served by restricting prisoners' access to craft and hobby materials and other in-cell activities, or subjecting them to routine strip searches even when the prisoner had no physical contact with others, and how such practices are conducive to rehabilitation and reintegration purposes or, indeed, to prison security. Such regimes are contrary to international standards and good practice and, in some cases, can be in violation of international law. Moreover, they result in boredom and frustration which may in turn lead to mental health and behavioural problems.

\subsection{Research findings and recommendations regarding prison design and environmental factors}

There are few studies of the relationship between the prison environment and prisoner behaviour in general, and no studies which focus on segregation units. The sparse literature and few empirical studies reaffirm the fairly obvious: "the design of the prison environment is crucial to its operation and to the impact it has on the achievement of correctional goals for inmates, staff and public users" (Fairweather, 2000:47): Environmental conditions in prison also affect prisoners' health and can "easily exacerbate the symptoms of mental illness for some people. In fact, the prison environment itself can contribute to increased suicide and the inability of inmates with serious mental illness to adjust. Environmental factors can also elicit significant adjustment reactions from inmates who may not have had a previous diagnosis but who become ill while incarcerated" (Hills at al. 2004:15). Further, design and environmental factors can influence the frequency and severity of violent incidents ${ }^{60}$.

The design of a prison is closely linked to its regime, as the layout of the prison dictates, to a large degree, the activities and human interaction that can take place within it. Studies of the effects of specific prison design features on prisoners and staff indicate that these can have'negative' or 'positive' effects. Positive design features are those that reduce the institutionalised atmosphere in prisons, lessen stress, aggression and violence, and generally increase prisoners' wellbeing. Negative features are those that foster and increase the above. Some of the design features that are cited as positively influencing behaviour and wellbeing are those which:

\section{Increase opportunities for social interaction between prisoners and between prisoners and staff}

Clearly, segregation units are not designed for continuous prisoner association. Yet, even in units or prisons designed for solitary confinement the design should allow for some degree of social interaction. This can be done through the inclusion of communal areas for recreational, sports and games facilities and so on. 


\section{Enable direct supervision of prisoners}

The prison's supervision style is determined by both its management approach and its architectural layout, and is cited by researchers as one of the most important factors in affecting behaviour. There are two basic layouts: direct supervision and indirect supervision. In prisons with indirect supervision, staff and prisoners occupy separate territories. Supervision and control are remote and characterised by reliance on distant visual surveillance from secure staff stations, and on patrolling corridors and landings. Indirect supervision is reactive in nature, and tends to alienate prisoners and staff. With direct supervision prisons, staff areas are located inside the unit, so that staff have greater face to face contact with prisoners. These prisons are proactive rather than reactive, as their layout and the presence of staff lessen opportunities for misconduct. Research suggests that direct supervision allows more effective surveillance and better security, and results in a dramatic reduction in prison violence ${ }^{61}$. Direct supervision has also been endorsed by professional bodies, as well as the United Nations, as the best method for managing prisoners, including those classified as dangerous or disruptive.

\section{Allow flexibility/ adaptability in the use of the unit}

Positive architecture allows adaptability to future change. Planning can anticipate, and the design should include, the possibility of future alteration of internal spatial divisions, external additions or subtractions, and 'functional flexibility'. New prefabricated technologies make it possible to design prison units so that they can serve different functions according to actual needs. So, for example, the division of space and design of a unit designated for long-term solitary confinement should not be so inflexible as to preclude the possibility of prisoner association areas or the provision of programmes, should there be a change in policies regarding the prisoners held in the unit or in their individual needs.

\section{Communicate a positive message}

The appearance of the prison communicates to prisoners how they are expected to behave (Wener, 2000:52). If the design and security arrangements in segregation and high security units communicate to prisoners that they are highly dangerous and not fit for human contact, they are more likely to start perceiving themselves as such and behave accordingly. Security arrangements should therefore be as limited and un-intrusive as possible and reflect the fact that segregated prisoners are already secured, individually, in their cells. It is also important to break the monotony of segregation units to allow a degree of sensory stimulation. This can be achieved easily and inexpensively by, for example, colourful wall paint, good lighting, and so on. 


\subsection{Human rights case law regarding regime and physical conditions in segregation units}

States have a duty to ensure that prisoners are "detained in conditions which are compatible with respect for his human dignity, that the manner and method of the execution of the measure do not subject him to distress or hardship of an intensity exceeding the unavoidable level of suffering inherent in detention and that, given the practical demands of imprisonment, his health and well-being are

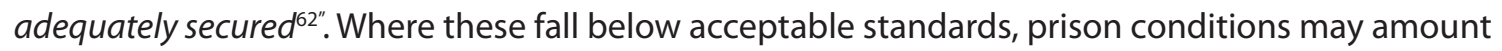
to inhuman or degrading treatment, in violation of international law.

Human rights bodies pay particular attention to the use of solitary confinement which, as the previous chapter noted, is viewed as an extreme prison practice, which should only be used in exceptional cases and then for the shortest duration possible. The ECtHR has stated that "complete sensory isolation coupled with complete social isolation can no doubt destroy the personality ${ }^{63 "}$ and would constitute treatment in violation of the absolute prohibition on torture, inhuman or degrading treatment enshrined in Article 3 of the European Convention on Human Rights. The Inter American Court of Human Rights has similarly stated in several cases that prolonged solitary confinement, in itself, may violate Article 5 of the American Convention on Human Rights: "prolonged isolation and deprivation of communication are in themselves cruel and inhuman treatment, harmful to the psychological and moral integrity of the person, and a violation of the right of any detainee to respect for his inherent dignity as a human being. Such treatment, therefore, violates Article 5 of the Convention..." ${ }^{64}$. Finally, the UN Human Rights Committee criticised "... the practice of solitary confinement which affected the physical and mental health of persons deprived of freedom and which amounted to a cruel, inhuman and degrading treatment ${ }^{\prime \prime 65}$.

In two separate cases brought against Uruguay, the Human Rights Committee found that holding a detainee for one month in a cell where "rainwater filtered in and one lives in the midst of human excrement" violated Article 10(1) of the ICCPR but not Article 7, whilst holding a detainee for one month in a small windowless cell where artificial light is left on 24 hours a day violated both Articles 10(1) and 7 of the ICCPR (UN Human Rights Committee, 1990, CCPR/C/OP/2). The UN Committee Against Torture (CAT) has found a violation of the prohibition against inhuman or degrading treatment or punishment in several cases involving the use of solitary confinement. For example, it found that isolation in cold and damp punishment cells measuring $1.5 \times 2$ metres without proper bedding or sanitation in Bolivia was "tantamount to torture", and the strict isolation in sound-proof cells of political prisoners in high security prisons in Peru amounted to torture ${ }^{66}$.

But solitary confinement may also constitute inhuman and degrading treatment when physical conditions are not so clearly below internationally established standards. When considering whether solitary confinement constitutes inhuman or degrading treatment in any one case, the courts and monitoring bodies will assess the surrounding circumstances, including: the particular conditions of confinement, the stringency of the measure, its duration, and whether the prisoner had minimal possibilities for human contact ${ }^{67}$. The objective pursued by the measure and its effects on the individual concerned will also be assessed ${ }^{68}$. As some of the cases below, drawn from judgements made by the ECtHR, demonstrate, both the physical conditions in which the 
prisoner is held and the degree of human contact he is afforded whilst in solitary confinement will be subjected to particularly close scrutiny. Where, in the Court's view, there are compelling reasons to hold a prisoner in separation from other prisoners, and the physical conditions of confinement are relatively comfortable, provisions are good and the extent of human contact is such that it is arguable whether the prisoner is really isolated, then case law suggests the Court is less likely to find a breach of the Convention ${ }^{69}$.

- The placement of a pre-trial detainee in solitary confinement for just under a year was found not to constitute inhuman or degrading treatment because although "a period of such a length may give rise to concern because of the risk of harmful effects upon mental health" the Court considered that the extent of social isolation to which he was subjected did not reach the necessary threshold and while "he was totally excluded from association with other inmates ... during the day he had regular contact with prison staff, [and] in addition, every week he received lessons in English and French from the prison teacher and he visited the prison chaplain. Also, every week he received a visit from his counsel. Furthermore, during the segregation period in solitary confinement the applicant had contact twelve times with a welfare worker; and he was attended to thirty-two times by a physiotherapist, twenty-seven times by a doctor; and forty-three times by a nurse. Visits from the applicant's family and friends were allowed under supervision". The Court also noted that the physical conditions of detention were adequate as the detainee was held in a cell measuring eight square meters equipped with a television set, and had access to newspapers (Rhode $v$. Denmark, Judgement of 21/7/2005, pars. 97-98).

- The Court found that a regime of strict solitary confinement (the prisoner was held alone in his cell for 23 hours a day and was only allowed to mingle with other prisoners for one hour during a daily walk) imposed on a former death row prisoner for over three years, and the material conditions in which he was held (cell measuring 2 by 3 metres with a small window which did not allow sufficient light or fresh air, a heating system which was covered by a layer of bricks and illumination by only one 60-Watt electric bulb which was insufficient for reading) must have "caused him suffering exceeding the unavoidable level inherent in detention" and constituted inhuman and degrading treatment in breach of Article 3 of the ECHR (lorgov v. Bulgaria, Judgement of 11/3/2004).

In sum, the extreme nature of solitary confinement and its potential health effects give rise to special human rights concerns, and its use is subjected to close scrutiny by the courts and monitoring bodies. In particular, the physical conditions in which prisoners are held, the regime provisions they enjoy and the degree of human contact they have whilst isolated will be assessed.

Although the human rights view is that solitary confinement is an undesirable prison practice, its use is not prohibited per se. Rather, the practice will be assessed on a case by case basis to determine whether it has violated the prohibition against torture, inhuman or degrading treatment or punishment. 


\subsection{Concluding remarks on regime and conditions of confinement in segregation and high security units}

Isolated prisoners spend up to 24 hours a day inside their cells. They have limited human contact, little or no physical contact with others, few personal possessions, and few ways to occupy themselves inside their cells. Prolonged confinement in these conditions is physically and mentally taxing. We discussed some of the potential health effects of solitary confinement in Chapter Two. These effects can be mitigated, to some degree, by ensuring that isolated prisoners:

- are accommodated in cells which are sufficiently large to enable them to conduct all their daily activities in a clean and humane environment, respectful of their human dignity;

- have daily access to fresh air and exercise;

- have access to meaningful human contact and purposeful activities; and,

- have contact visits with family members.

The deprivations inherent in segregation units should not be made worse by further restrictions on in-cell provisions such as reading materials, craft and hobby materials, personal radios and so on. Wherever possible, prisoners should be allowed to conduct daily activities in association with other prisoners. Where there are compelling reasons not to allow prisoner association, increased contact with staff, particularly non-custodial (religious, educational, health) staff should be encouraged. Custodial staff should also be encouraged to engage informally with prisoners and maintain good relationships and a good atmosphere in the unit. It is thus crucial that staff working in segregation units are carefully selected, well supported and properly trained. In particular, staff should receive training in mental health and de-escalation techniques. Well trained, experienced staff can make a huge difference in segregation units.

In short, every effort should be made to ensure that the harmful aspects of solitary confinement are mitigated through the provision of decent facilities, sensible regimes and purposeful activities. Adherence to the standards discussed in this chapter is not only legally required, but it also makes good managerial sense. Even when all these mitigating factors are in place, solitary confinement should not, as discussed in Chapter Three, be used for a prolonged time other than in a handful of cases where it may be exceptionally and absolutely necessary. 


\section{Key points}

- Isolated prisoners spend most of their time inside their cell. Cells should therefore be designed to accommodate this regime and, as a minimum, contain a toilet and a wash-basin.

- Allow segregated prisoners to exercise some degree of autonomy and control over their immediate environment.

- Encourage visits by family and friends and ensure that visiting areas are clean and in good decorative order.

- Ensure that isolated prisoners have as much human contact as possible with people from outside the prison and with custodial, educational, religious and medical staff.

- Allow for as many activities as possible, for example meals, to take place in association with other prisoners.

- Where this is not possible, creative solutions should be sought to ease the restrictive monotonous environment and impoverished regime in segregation units.

- Small concessions go a long way. Be flexible and think creatively.

- One size does not fit all. Additional restrictions may be unavoidable for certain prisoners at certain times, but should not be applied as a matter of course.

- The recommendations discussed in this chapter set out minimum standards which prison administrations should strive to improve on.

- Further standards and safeguards need to be developed to ensure that prisoners are protected against the harm that solitary confinement causes. 


\section{Notes}

56 U.N. Doc. CCPR/C/51/D/458/1991; Mukong v. Cameroon (August 10, 1994).

57 Royal College of Psychiatrists, 1998; Buchanan et al. 1988; Fairweather, 2000.

58 Poltrotsky v Ukraine, 146 ECHR 2003-V; See also judgements in the cases of Kuznetsov; Nazarenko; Dankevich; Aliev; Kokhlich v Ukraine, judgments of 29 April 2003, ECHR 2003-V.

59 Moyer, 1975:58-60; Fairweather 2000:34. The Royal College of Psychiatrists' Clinical Practice Guidelines propose that staff working with the mentally ill should "Encourage and provide privacy for visits from friends and relatives" as good practice in preventing violence (1998:59).

60 Management of imminent violence, Royal College of Psychiatrists OP41 (1998).

61 Fairweather, 2000; Bottoms, 1999:243-245; Buchanan et al., 1988:51-54

62 Kudła v. Poland [GC], no. 30210/96, 92, ECHR 2000-XI

63 Ensslin, Baader and Raspe v. FRG, DR14 (1978) at Para. 109.

64 Velasquez Rodriguez v. Honduras, Judgement of 29 July 1988, Series C No.4 at par. 156

65 UN Human Rights Committee (2001) A/56/156. November 3rd, 2000, session.

66 UN Committee Against Torture (2001) paragraphs 95(g) and 186 respectively.

67 Ensslin, Baader and Raspe v FRG 14 DR 64 (1978).

68 McFeeley and Others v. the UK, no. 8317/78, Commission decision of 15 May 1980, DR 20

69 The placement of a prisoner, Ilich Ramirez ('Carlos the Jackal'), who, at the time, "was considered to be the most dangerous terrorist in the world", in solitary confinement for more than eight years was found not to violate Article 3. In reaching its decision, the Court took account of the relatively comfortable conditions of his detention (his cell measured 6.84 sq. meters, was equipped with a toilet and washing facilities and had a window which provided natural light. He also had access to a television, newspapers and books), the fact that he was allowed out of his cell two hours daily for outdoor exercise and one hour in a gym, had frequent contact with people from outside the prison (he was visited by a doctor twice a week, by a cleric once a month, and frequently by his 58 lawyers, including 640 times in a period of five years by one of his lawyers, whom he later married), and, by his own testament, was in good physical and mental health. The Court also noted that he was later removed to a normal prison location, whilst reaffirming that in any case, solitary confinement should not be imposed on the prisoner indefinitely (Ramirez v. France, Judgement of 27/1/2005). 


\section{$5 \mid$ The role of health professionals in segregation units: ethical, human rights and professional guidelines ${ }^{10}$}

\subsection{Introduction: ethics as applied to prison medicine}

Health professionals working in prisons and other places of detention face some particular challenges which stem from the inherent tension between the role of the prison as a place of punishment through deprivation of liberty, and their role as protectors and promoters of health (physical, mental and social). Firstly, they need to provide care in an environment which is geared towards security and all the physical arrangements - and institutional culture - that this entails. Their patients are held involuntarily in conditions which severely limit not only their freedom of movement, but the degree of control they have over most other aspects of their daily lives and activities. Other challenges include a high workload, often coupled with limited resources; work with populations with special needs and high prevalence of mental illness; dual obligations towards their patients and the prison's authorities; the competing demands of each and potential mistrust by both; poor training and, where they are employed exclusively by the prison, a degree of isolation from other members of their profession ${ }^{71}$.

The ethical challenges are especially acute when the question of the involvement of health personnel in disciplinary measures arises, and nowhere is this more contentious than in their role, if any, in segregation units $^{72}$.

By asking a number of pertinent questions, the following section outlines the ethical and legal framework that guides the role of health personnel when confronted with the use of solitary confinement. Some of the potential dilemmas and conflicts identified below are not always easy to resolve in practice. Nonetheless, health professionals must always ensure that their conduct is not compromised by external and possibly spurious considerations. When faced with such dilemmas, advice and guidance should always be sought from senior health colleagues and from professional bodies. 


\subsection{Issues regarding prison medicine in solitary confinement units}

What are 'dual loyalties' and where can health professionals seek support and advice?

A physician shall owe his/her patients complete loyalty and all the scientific resources available to him/her (WMA International Code of Medical Ethics, 1949).

A situation of dual loyalty arises when health professionals face "simultaneous obligations, expressed or implied, to a patient and a third party"73. Health professionals working in prisons will almost inevitably face situations where they are asked or expected to suspend their clinical judgement in favour of other considerations or to contribute to processes and procedures that are not driven by therapeutic purposes. Codes of ethics make it clear that the duty owed to the patient takes precedence over any other obligation, and that health professionals must act in the best interest of their patients at all times. Many of the issues outlined in the following sections, such as whether to certify someone fit for punishment, or the right to access healthcare, are examples of such dual loyalties.

Clearly, as in any medical practice, there will be situations in which health professionals will have to judge whether their primary obligation to the care of the individual patient might have to be overridden in order to protect that individual, other prisoners, or staff. Again, their actions should be guided primarily by their function as health professionals, above that of their status as employees of a prison, police force or the military, but therein lies the very essence of "dual loyalties". Health professionals should strive to retain a professional independence, and thereby to retain the trust and confidence of their prisoner-patient.

Physicians seeking advice on ethical dilemmas can approach both their national medical association and the World Medical Association ${ }^{74}$ (www.wma.net). Nursing professionals can approach their national nursing association as well as the International Council of Nurses, the body which provides ethical guidance to nurses (International Council of Nurses www.icn.ch).

\section{Do health professionals have any role in certifying a prisoner 'fit' to undergo disciplinary measures, including solitary confinement?}

In exactly the same manner as any health professional working in the community, the primary duty of the health professional working inside a prison is to protect, promote and improve the health of their patients. Naturally, when working in an environment whose over-arching aim is security, the health professional must follow the rules and procedures necessary for the safe and lawful running of the institution, but their role as health professionals must not be subordinated to this purpose. Their ethical duties remain the same as if they were working in the community but, as we shall see below, with the various constraints that working in a place of deprivation of liberty brings. 
"Act only in the patient's interest when providing medical care which might have the effect of weakening the physical and mental condition of the patient" (World Medical Association International Code of Medical Ethics 1949, amended 1983).

It is clear that for health staff to participate in any manner in disciplinary measures within a prison would, in the first place, be in direct contradiction with their fundamental role as healthcare providers. The primary duty of the physician and the nurse, wherever they work, is to the health of their patient (World Medical Association Declaration of Geneva 1949, amended 1994, and International Council of Nurses Code of Ethics for Nurses, adopted 1953 and revised 2005). Moreover, in order to establish and to maintain the professional relationship and confidence and trust with the prisoner-patient, the prison health staff cannot be seen to have any role in the prison administration, and in particular in disciplinary matters. Health care must be provided with "full technical and moral independence" and be based purely upon medical needs (World Medical Association International Code of Medical Ethics 1949, amended 1983, and International Council of Nurses Position Statement on Nurses' Role in the Care of Prisoners and Detainees 1998, revised 2006).

"It is a contravention of medical ethics for health personnel, particularly physicians...to certify, or to participate in the certification of, the fitness of prisoners or detainees for any form of treatment or punishment that may adversely affect their physical or mental health and which is not in accordance with the relevant international instruments, or to participate in any way in the infliction of any such treatment or punishment which is not in accordance with the relevant international instruments" (Principle 4 (b), United Nations Principles of Medical Ethics ${ }^{75}$ ).

International standards of medical ethics thus clearly state that health professionals, particularly physicians, must neither certify someone "fit for punishment", nor participate in any way in the administering of such punishment. When isolation is used for any purpose that is not purely medical (e.g. isolating a potentially infectious patient), health staff can have no part in the process of deciding on its application or its administration.

It has often been argued that the physician can have a protective role by examining the fitness of individuals to undergo certain punishments. Indeed, the UN Standard Minimum Rules, which date from the 1950s and from a more 'paternalistic' view of medical ethics state that "Punishment by close confinement or reduction of diet shall never be inflicted unless the medical officer has examined the prisoner and certified in writing that he is fit to sustain it" (Rule 32. (1)). Standards evolve over time, however, and this rule is now clearly at odds with contemporary standards of medical ethics (see above) as well as current standards of prison administration and treatment of prisoners which, obviously, would not allow a reduction in the basic nutrition of any prisoner as a punishment. Looking at the issue from another perspective, were the physician to decide that certain prisoners are not fit to undergo solitary confinement, those people may well be spared the punishment. But this also means that in other cases the physician is effectively authorising the punishment of placing another prisoner in solitary confinement. Not only are they certifying someone fit for punishment, but they are acquiescing in a punishment that is known to adversely affect mental and physical health. 
But there is a more decisive argument. The Sourcebook has set out the substantial body of research that shows the deleterious effects of solitary confinement on the mental and physical health of individuals, even if only inflicted for relatively short periods. The fact that in several international prison standard instruments and in many national prison regulations particular attention is given to solitary confinement and to attempts to mitigate its negative effects by involving health staff in its application, is a clear indication that the potentially harmful consequences are known to those writing them. Put more simply, if solitary confinement is safe, why must a physician check that someone can withstand it, and why must they be required to monitor their physical and mental health on a daily basis? No other legal disciplinary measure requires so much medical oversight.

For these reasons, the World Health Organisation (WHO) recommends that "doctors should not collude in moves to segregate or restrict the movement of prisoners except on purely medical grounds, and they should not certify a prisoner as being fit for disciplinary isolation or any other form of punishment" (Health in Prisons, A WHO Guide to the essentials in prison health 2007:36). The official commentary on the revised European Prison Rules (EPR) similarly states that "medical practitioners or qualified nurses should not be obliged to pronounce prisoners fit for punishment but may advise prison authorities of the risks that certain measures may pose to the health of prisoners" ${ }^{117}$.

\section{Do health professionals have any role in monitoring the effects of a disciplinary punishment once it has started?}

From the previous paragraphs it is clear that health staff have no role in prison discipline, and that this includes monitoring the health effects of a sanction once it is being carried out. If the health professional, of their own volition and following their medical judgement rather than as 'standard procedure', was to chart the appearance of negative health effects, and at a given point intervene to end a disciplinary sanction, then effectively they are acting as arbiter of how long particular individuals can withstand the punishment. Inevitably, they will then have to decide that some individuals must be removed from isolation, while others must remain isolated (while knowing that the latter may sooner or later develop psychological, psychiatric or physical disorders linked to the isolation).

Monitoring the potential health consequences must, however, be distinguished from the right of all prisoners, irrespective of their status, location, or behaviour, to access healthcare (this will be discussed in more detail in the following section). Again, herein lies one of the key tensions of dual loyalty, since there is clearly a fine line between monitoring the punishment and providing needed clinical attention and care.

The revised version of the European Prison Rules (2006) states that solitary confinement should be an exceptional measure, and that even then it should only be applied for the shortest possible time (Rule 60.5). The Rules then require that medical staff should monitor prisoners in solitary confinement on a daily basis, and emphasise that if their mental or physical health is "seriously at risk", this must be reported to the director ${ }^{77}$. Similarly, the CPT in its early general reports foresaw a monitoring role for physicians (CPT 2nd General Report, CPT/Inf (92) 3 Para. 56). 
However, in an often overlooked footnote contained in the revised European Prison Rules the government of Denmark objected to the proposed role of physicians in monitoring those in solitary confinement, on the basis that this could constitute certifying that the person is fit to continue the punishment of solitary confinement, which would be unethical. The objection could also have been made on the basis that this particular treatment may amount to a form of ill-treatment and not only would the participation of health staff be unethical, it would also be a contravention of international law. Addressing this ethical issue, the official commentary on the revised Rules stipulates that daily visits to isolated prisoners "can in no way be considered as condoning or legitimising a decision to put or to keep a prisoner in solitary confinement".

\section{What if the disciplinary measure actually or potentially inflicts injury?}

It is self-evident that if acts of torture or other cruel, inhuman or degrading treatment are prohibited by international law, health professionals are also bound by such laws. Furthermore, their conduct is also constrained by international ethical standards which clearly prohibit not only active participation in interrogation, but also any other acts such as devising or planning methods of interrogation, particularly when the use of medical knowledge is solicited or when confidential medical information is misused against the patient ${ }^{78}$. The World Medical Association's Declaration of Tokyo states in its paragraph 3:

"When providing medical assistance to detainees or prisoners who are, or who could later be, under interrogation, physicians should be particularly careful to ensure the confidentiality of all personal medical information. A breach of the Geneva Conventions shall in any case be reported by the physician to relevant authorities. The physician shall not use nor allow to be used, as far as he or she can, medical knowledge or skills, or health information specific to individuals, to facilitate or otherwise aid any interrogation, legal or illegal, of those individuals".

Ethical standards also clearly dictate that if health professionals are aware or suspect that a criminal or other illegal act is planned or has taken place in a prison or other place of detention, they are obliged to report this act through the appropriate channels, and it is these authorities who will decide if there is criminal liability and what action is to be taken. Understandably, acting to report or denounce actions of colleagues (sometimes known as "whistle blowing") is a very delicate issue, and in some States may even endanger the life of the person reporting such cases. In countries where there is a degree of impunity for particular authorities, then there may be separate channels established to allow confidential reporting of incidents. The World Medical Association has specifically stated that fellow professionals should provide support and protection to physicians who are either pressured to participate in acts of torture or other ill-treatment, as well as to those physicians who report and denounce such acts (WMA Declaration of Hamburg ${ }^{79}$ ).

Thus, if the use of solitary confinement is considered to be inhuman or degrading treatment, and in some cases torture, then it would be contrary both to international law and to international standards of medical ethics for physicians and other health professionals to participate in the practice in any way, or to condone or acquiesce to its use. In those instances where the negative health effects of solitary confinement are deliberately used as a tool for interrogation purposes, 
either to mentally or physically weaken the individual, or to instil disorientation, dependence, fear and so on, then this may amount to torture or to cruel, inhuman or degrading treatment, contrary to international law and standards of medical ethics. Health professionals involved in such acts will be culpable to the same degree that the prison or security forces are culpable. Similarly if a physician or any other health staff divulge confidential medical information on a patient primarily to serve the purposes of the interrogation, this would be unethical, and in those cases where the interrogation amounts to torture or other ill-treatment, this would amount to complicity in those acts or omissions.

\section{Does a prisoner in solitary confinement lose the right to access healthcare?}

No. It is a matter of international law that every person, including all prisoners (regardless of their location within a prison, and regardless of any disciplinary infraction they may have committed), retain the right to access and receive appropriate health care ${ }^{80}$. This right places a positive duty on prison authorities and governments to provide prisoners with a level of healthcare equivalent to that provided in the community, and this obligation should be reflected in national legislation and national prison rules and regulations. In England and Wales, the principle of equivalence of care has been endorsed by Parliament and incorporated into the Prison Service's standards and guidelines ${ }^{81}$. This requirement excludes the right to choose one's own doctor (BMA 1992:177).

The ethical obligation to provide healthcare to prisoners on an equivalent level to that available in the local community is also clearly stated in several international instruments:

Health personnel, particularly physicians, charged with the medical care of prisoners and detainees have a duty to provide them with protection of their physical and mental health and treatment of disease of the same quality and standard as is afforded to those who are not imprisoned or detained (Principle 1 of the UN Principles of Medical Ethics relevant to the Role of Health Personnel, 1982)

Thus anyone placed in solitary confinement, for however long, does not forfeit the right to request medical attention, to be seen without delay, and to receive treatment appropriate to the nature and gravity of the problem.

As in any other section of the prison, prison staff may alert the health staff to potential or actual health problems that the prisoner himself may not have noticed. In the first instance this should be done with the consent of the prisoner, who may not wish to see a member of the health staff, but if the staff consider that the condition may be a risk to the individual then they should alert the health staff. It is also recommended that, where they have concerns about a particular prisoner in solitary confinement, doctors visit that prisoner at their own initiative, even if the prisoner did not request this (WHO Health in Prisons, 2007:36). This is good practice, which is in line with principles of assertive community treatment outside the prison.

Finally, prisoners' right to health has been recognised as an integral part of wider public health promotion and protection in the community, because prisoners are a part of society, with the vast majority passing through prison for relatively short periods before returning to the community. 
Health issues within prisons usually mirror and amplify health issues in the community, so ignoring prison health effectively means that community public health is not fully attended to. This is best summarised by the WHO, who have stated that "prison health is public health"82.

\section{Do prisoners in segregation have the right to confidential medical examinations and confidentiality of their medical files?}

Again, the health staff must at all times distinguish themselves from custodial staff and, while it is accepted that in a very few cases the health staff may need to take precautions against a potentially violent prisoner, medical examinations should be carried out in a manner which is respectful of the patient's right to privacy and allows for confidentiality to be maintained. If a relationship of trust and confidence has been established between health staff and the prisoner from the outset, then excessive security measures are rarely warranted.

Particular challenges to the principle of medical confidentiality may arise in high security and segregation units because of their security arrangements, and because they house prisoners who are regarded as high risk. This may mean, for example, that all areas of the unit are covered by CCTV, limiting the availability of private spaces in which to conduct the examination. In some situations the custodial staff may insist that medical interviews with prisoners are conducted through a glass partition, or that the prisoner is handcuffed or otherwise physically restrained, or they may insist on remaining in close proximity whilst the medical examination takes place. The previous discussion on the duties of health staff to provide an equivalent level of healthcare within prisons and to follow the same ethical practice as they must outside the prison makes it clear that such security measures would interfere with the doctor-patient relationship. It should also be noted, however, that such security measures also interfere with proper clinical care. It is obvious that conducting any kind of medical interview or intervention through either a glass partition or through the viewing slot of a cell door is unacceptable clinical practice. There will of course be instances where an individual has a proven history of violence or threats, and consideration must naturally be given to the safety of health staff. But this must be done on a case by case basis, and not form a blanket policy for all consultations with the prison population.

Thus, a prisoner in solitary confinement should be seen in the prison health centre just like any other patient. The use of restraints during a medical consultation not only interferes with the clinical procedure but can damage the relationship between the prisoner-patient and the health staff, since the latter are seen as just another facet of the security system. The need for any extra security for a specific prisoner must be assessed, and periodically reassessed, on an individual basis, preferably by an interdisciplinary group comprising of health professionals, custodial staff and management, and using established risk assessment protocols. Where a serious threat of violence does exist, health and custodial staff should attempt de-escalation techniques first, and any additional security measures deemed necessary by custodial staff should be taken on the basis of proportionality and using the minimum means necessary. Further, more attention should be given to making the examination room safe and secure than to the ultimate measure of restraining the patient ${ }^{83}$. If there is thought to be a significant risk, then some form of 'panic button' should be available in the room, and if prison staff insist on remaining close to the patient, they may remain in sight, but must be out of hearing distance of the consultation. 
The General Medical Council's (UK) Good Medical Practice Guidelines (2006) require doctors to respect the patient's right to dignity and confidentiality and the expectation is that prisoners will be examined without restraints and without the presence of prison officers unless there is a high risk of violence. Where such high risk is present, the patient's privacy, dignity and confidentiality should be maintained as much as possible (British Medical Association (BMA) Ethical Guidance, 2004). Practice shows that the circumstances in which doctors need to compromise on privacy and confidentiality are very few, and this should be a guiding principle when accepting restrictions on clinical practice. Ultimately doctors operate professional judgement and have to balance the needs of their patients against the needs for security and safety. Experience shows that the latter rarely needs to override the former.

Once a medical examination is conducted and medical notes are made, health professionals have a duty to hold information on their patients in confidence.

A physician shall respect a patient's right to confidentiality. It is ethical to disclose confidential information when the patient consents to it or when there is a real and imminent threat of harm to the patient or to others and this threat can be only removed by a breach of confidentiality (World Medical Association International Code of Medical Ethics, 1949).

This requirement is central to the doctor-patient relationship, and without the assurance of confidentiality, patients may be reluctant to give information to their health-care providers. Establishing trust and a good doctor-patient relationship in the prison setting is potentially even more difficult than it is outside the prison, as medical staff may be identified by prisoners as being part of the prison's authorities. Further, medical staff may face pressures to disclose information to non-medical prison staff who mistakenly feel that they have a right to know such information for their own protection. Good practice guidelines make it clear that any disclosure of confidential information must adhere to established principles of medical ethics, and doctors making such disclosure must always be prepared to justify their decision in accordance with these principles ${ }^{84}$. As stated in the International Code of Ethics, there will of course be situations in which the health professional may judge that a real and imminent threat exists, either to the patient himself or to other prisoners or staff, and which may necessitate disclosing limited medical information to assist in protecting the patient or others. This would be the case, for example, if a patient is judged to have suicidal ideas which they could act upon. The doctor may then judge that they must disclose some information for the patient to be put on "suicide watch". In cases where the health professional feels that a prisoner threatened harm against another prisoner or staff, in a way which suggested a very real risk of the threat being carried out, then they must consider reporting such a threat in order to protect the potential victim. 


\subsection{Case law regarding the provision of medical care in prison}

Failure to provide adequate medical care in prisons not only raises ethical issues, but may also breach prisoners' human rights under international law. In examining the question of access to appropriate medical care in prisons and detention centres, some of the following principles have been established.

- Prison authorities have an obligation to protect the health of persons deprived of liberty (Hurtado v Switzerland 1994 Series A. No. 280 par. 79) and are required to provide medical assistance and treatment to those held in their custody (Aers v Belgium 1998, Reports 1998-V).

- This obligation is not dependent on the prisoner's behaviour: "It must be stressed in this respect that the applicant's alleged rude behaviour towards medical staff and, indeed, any violation of prison rules and discipline by a detainee, can in no circumstances warrant a refusal to provide medical assistance" (lorgov v. Bulgaria, 2004 par. 85).

- Failure to provide appropriate medical care to a prisoner who clearly needs it may amount to inhuman or degrading treatment in breach of Article 3 of the ECHR (Beceiev and Sorban v. Moldova, 2005; McGlinchey v. UK, Application 50390/99 ECHR 2003-V).

- An increased standard of vigilance is required where a vulnerable person, for example a mentally ill prisoner, is involved, taking into account their vulnerability and their inability, in some cases, to complain coherently or at all about how they are being affected by their conditions of detention (Herczegfalvy v. Austria, 199315 EHRR 437).

\section{Case study: the death of Mark Keenan ${ }^{85}$}

Mark Keenan was 28 years old when he died from asphyxia caused by hanging in his cell at Exeter prison. His medical history included symptoms of paranoia, aggression, violence and deliberate self-harm. He was previously diagnosed as suffering from paranoid schizophrenia and, from the age of 21 , was intermittently treated with anti-psychotic medication.

\section{Facts of the case}

On April 1st 1993 Mark Keenan was convicted of an assault on his girlfriend and sentenced to four months imprisonment. He was admitted to Exeter prison where he was initially placed at the prison's health centre for observation and assessment. When it was suggested on April 14th that he could be moved to an ordinary location at the prison, he barricaded himself at the health centre in protest. On April 16th he was discharged to ordinary location but was returned to the health centre the following evening after his cell-mate reported that he had made a noose from his bed sheet. He was placed in an unfurnished cell and placed on a 15 minute watch. On April 26th there was another attempt to return him to ordinary location, but he was again returned to the medical centre the following day. On April 29th he was assessed by the prison's visiting psychiatrist who prescribed a change in his medication, and recommended that he should not associate with other prisoners until his panic subsided. The following day the possibility of movement to ordinary location was raised again. Mark Keenan said that he did not feel fit for the move. In the course of the day his mental state deteriorated, with evidence of aggression and paranoia. The doctor, who 
had no psychiatric training, considered that this might be because of the change in his medication, and prescribed a return to his previous medication. At $6 \mathrm{pm}$ that day Mark Keenan assaulted two hospital officers and was placed in an unfurnished cell and put on a 15 minute watch. On May 1st the prison's senior medical officer, who had six months training in psychiatry, certified him fit for adjudication in respect of the assault, and fit for segregation. Whilst in the segregation wing, Mark Keenan appeared agitated and distressed and was threatening to harm himself. He was transferred again to an unfurnished cell in the hospital wing where he continued to appear agitated and was aggressive towards staff.

On May 3rd his medical notes recorded that Mark Keenan's attitude was 'very much better', and that he had requested to be returned to the segregation unit. Back at the segregation unit, it was noted that he seemed better but still needed watching. It was further noted that he stated that he felt that he was about to 'go off on one'. The medical notes from that evening recorded that he was being troublesome and given extra medication. There were no further entries in his medical notes until his suicide on May 15th, although entries in the segregation unit's log indicated that he was 'acting very strangely'. On May 14th, nine days before his expected release date and two weeks following the event, adjudication in respect of his assault on the officers took place and he was awarded 28 additional days in prison, and seven days in punitive segregation. The following morning he was seen by the chaplain, the doctor, and visited by a friend. They all later recalled that he seemed calm if unhappy about his punishment. At 18:35 that evening Mark Keenan was found dead in his cell. There was indication that sometime prior to hanging himself he pressed the panic button in his cell.

\section{The court's findings}

Assessing whether Mark Keenan's treatment violated Article 3 of the ECHR, the Court found that it had, and was particularly critical of the level and standard of medical care he received: "the Court is struck by the lack of medical notes concerning Mark Keenan, who was an identifiable suicide risk and undergoing the additional stresses that could be foreseen from segregation ... the lack of effective monitoring of Mark Keenan's condition and the lack of informed psychiatric input into his assessment and treatment disclose significant defects in the medical care provided to a mentally ill person known to be a suicide risk. The belated imposition on him ... of a serious disciplinary punishment... which may well have threatened his physical and moral resistance, is not compatible with the standard of treatment required in respect of a mentally ill person"(at pars. 113-115). 


\section{Key points}

- Health staff must not participate in disciplinary procedures in any way, particularly in certifying prisoners fit to withstand procedures, including solitary confinement.

- Where the use of solitary confinement is abusive and may amount to torture or other forms of ill-treatment, health staff have a duty to report and denounce such acts to the appropriate authorities and professional bodies.

- Prisoners in solitary confinement, just like other prisoners, have the right to an equivalent level of medical care to that available outside the prison

- The providers of medical care in prison are bound by the usual established principles of medical ethics, in particular the confidentiality of medical information.

- It is the duty of medical personnel to familiarise themselves with these principles 
Notes

70 This chapter was co-authored with Jonathan Beynon, MD, Medical Co-ordinator for Health in Detention, International Committee of the Red Cross. Thanks are also due to Julian Sheather of the Medical Ethics Department of the British Medical Association for his insightful comments on a draft of this chapter. The points of view expressed here represent the personal opinions of the authors, and do not necessarily represent the position of their organizations

71 For further discussion see: British Medical Association (2001) The Medical Professions \& Human Rights: Handbook for a changing Agenda, Zed Books, London \& New York, particularly chapter 5.

72 This chapter does not aim to address the range of issues of medical ethics as applied in places of deprivation of liberty, but focuses on the conflicts and issues related to the use of solitary confinement.

73 Dual Loyalty \& Human Rights in Health Profession Practice, Physicians for Human Rights and the School of Public Health and Primary Health Care, University of Cape Town, 2002:I

74 The World Medical Association (WMA) formed in 1948 in direct response to the horrors perpetrated by the Nazi regime, and in particular by the direct participation of Nazi doctors in many of the atrocities, has as one of its principal aims the adoption and promotion of international standards of medical ethics. The WMA Declaration of Geneva is a modern version of the Hippocratic Oath, the pledge of service to mankind implicit in the work of all physicians.

75 Principles of Medical Ethics relevant to the role of health personnel, particularly physicians, in the protection of prisoners and detainees against torture, and other cruel, inhuman or degrading treatment or punishment. Adopted by General Assembly resolution 37/194, 18 December 1982.

76 Commentary to Recommendation REC(2006)2 of the Committee of Ministers to Member States on the European Prison Rules, Commentary on Rule 43.

77 European Prison Rules. Council of Europe Committee of Ministers Recommendation Rec (2006)2. Rule 43.2: The medical practitioner or a qualified nurse reporting to such a medical practitioner shall pay particular attention to the health of prisoners held under conditions of solitary confinement, shall visit such prisoners daily, and shall provide them with prompt medical assistance and treatment at the request of such prisoners or the prison staff. And Rule 43.3: The medical practitioner shall report to the director whenever it is considered that a prisoner's physical or mental health is being put seriously at risk by continued imprisonment or by any condition of imprisonment, including conditions of solitary confinement.

78 World Medical Association, Guidelines for Medical Doctors Concerning Torture and Other Cruel, Inhuman or Degrading Treatment or Punishment in Relation to Detention and Imprisonment, Adopted by the 29th World Medical Assembly Tokyo, Japan, October 1975 and revised 2006 (Known in abbreviated form as the Declaration of Tokyo). Article 1: "The doctor shall not countenance, condone or participate in the practice of torture or other forms of cruel, inhuman or degrading procedures... ". Also: International Council of Nurses, Position Statement on Torture, Death Penalty and Participation by Nurses in Executions, 1998

79 Declaration of Hamburg. World Medical Association. Concerning Support for Medical Doctors Refusing to Participate in, or to Condone, the Use of Torture or Other Forms of Cruel, Inhuman or Degrading Treatment Adopted by the 49th WMA General Assembly Hamburg, Germany, November 1997

80 The right to health in international human rights law is stipulated in the International Covenant on Economic, Social and Cultural Rights, and detailed in General Comment No.14 of the Committee on Economic Social and Cultural Rights ('The right to the highest attainable standard of health' (11 August 2000) UN Doc E/C.12/2000/4 par. 1). See also Rule 22 of the UN Standard Minimum Rules and Rule 40 of the European Prison Rules.

81 Prison Service Order 3200; PSI 5/2003. See also: Joint Parliamentary Committee on Human Rights (2004), Third Report Session 2004-05, HL 15/I/HC 137-I; All Parliamentary Group on Prison Health (2006), The Mental Health Problem in UK HM Prisons.

82 World Health Organization Europe, The Moscow Declaration: Prison Health as part of Public Health, 24 March 2003

83 The use of restraints for medical purposes, for example with an acutely psychotically disturbed patient, is governed more by clinical judgement for protecting the individual patient or others than purely on the grounds of security or prison management.

84 For further guidance see: General Medical Council, Good Practice Guidance on Confidentiality: Protecting and Providing Information, April 2004; British Medical Association Medical Ethics Today, 2004; Royal College of Psychiatrists, Good Psychiatric Practice: Confidentiality and Information Sharing, CR 133, 2006

85 Keenan v. The United Kingdom, Application No. 27229/95, ECtHR Judgement of 3 April, 2001. 


\section{Monitoring and inspecting solitary confinement units}

All the aspects of solitary confinement discussed in this Sourcebook - placement, conditions of confinement, regime, contact with the outside world, and the provision of medical care - should be subject to close scrutiny and review by national and international inspecting bodies.

The importance of installing mechanisms for inspection and scrutiny of all prisons and other places of detention is emphasised in international and regional instruments:

There shall be a regular inspection of penal institutions and services by qualified and experienced inspectors appointed by a competent authority. Their task shall be in particular to ensure that these institutions are administered in accordance with existing laws and regulations and with a view to bringing about the objectives of penal and correctional services (SMR Rule 55; Body of Principles Principle 29(1); EPR Rules 9, 92, 93).

In addition to physically inspecting places of detention, the inspecting body should have full and free access to those held within:

A detained or imprisoned person shall have the right to communicate freely and in full confidentiality with the persons who visit the places of detention or imprisonment in accordance with paragraph I of the present principle, subject to reasonable conditions to ensure security and good order in such places (UN Body of Principles for the Protection of All Persons Under Any Form of Detention or Imprisonment, Principle 29(2)).

Inspections are particularly important in segregation units, as they are closed units within closed establishments, shut off not only to the outside world, but also to other sections of the prison and to the prison society at large. As the principles cited above make clear, the inspecting body should have unhindered access to both the physical facilities at the unit, and to prisoners held in them. The inspecting body should also have access to relevant documentation, for example records of placement and review hearings, the unit log and records, CCTV footage and so on. Health staff on the visiting team must have full access to the medical registers and records. Inspectors should ensure that segregated prisoners have the opportunity to talk about their treatment privately and confidentially.

Under Article 14 of the Optional Protocol to the UN Convention against Torture (OPCAT), State Parties undertake to grant the Sub-committee on Prevention of Torture and Other Cruel, Inhuman or Degrading Treatment or Punishment: 
1 (a) Unrestricted access to all information concerning the number of persons deprived of their liberty in places of detention as defined in article 4, as well as the number of places and their location;

(b) Unrestricted access to all information referring to the treatment of those persons as well as their conditions of detention;

(c) Subject to paragraph 2 below, unrestricted access to all places of detention and their installations and facilities;

(d) The opportunity to have private interviews with the persons deprived of their liberty without witnesses, either personally or with a translator if deemed necessary, as well as with any other person who the Subcommittee on Prevention believes may supply relevant information;

(e) The liberty to choose the places it wants to visit and the persons it wants to interview.

2. Objection to a visit to a particular place of detention may be made only on urgent and compelling grounds of national defence, public safety, natural disaster or serious disorder in the place to be visited that temporarily prevent the carrying out of such a visit. The existence of a declared state of emergency as such shall not be invoked by a State Party as a reason to object to a visit.

The inspecting body will examine some of the following ${ }^{86}$ :

- Was the decision to place the prisoner in segregation taken in accordance with the law?

- What were the reasons for placing the prisoner in the unit, is the prisoner aware of these reasons and was he given an opportunity to appeal against his placement?

- Is the placement decision reviewed on a regular basis?

- Do physical conditions of detention (cells, shower area, exercise yards) comply with the required standards?

- Do prisoners have access to adequate medical care?

- Are medical records being kept in good order in a secure place?

- Do prisoners have access to an appropriate regime?

- Do prisoners have regular access to an outside area?

- Do prisoners have contact with the outside world?

Nationally inspections are usually carried out by a body appointed by the ministry in charge of prisons, and report to it. They may also appoint a local watchdog body to provide regular monitoring of individual prisoners between inspections. These bodies will pay particular attention to segregation units and to the use of force and restraints. 
Case study: Extreme Custody: a report by HM Chief Inspector of Prisons for England \& Wales.

In 2006 HMCIP carried out a thematic review of all the segregation units in the High Security Estate (HSE) and of the Close Supervision System (CSC) designed to manage disruptive prisoners. These were the units where prisoners were held in isolation in the most restricted and controlled environments with the most potential for prisoner damage. The thematic review followed previous criticisms of the approach of staff in high security segregation units from coroners and others.

The report charted the progress that had been made - some of it innovative, particularly in integrating mental health approaches with custodial care - but also pointed out the distance still to travel. The inspection exposed a hard core of long stay prisoners in segregation units who had complex needs and who could not be managed safely elsewhere. Though there was some psychiatric and therapeutic support in the units, it was not enough, and many prisoners were deteriorating further in lengthy solitary confinement. HMCIP recommended individual, multidisciplinary and properly resourced care plans to ensure that prisoners' health was supported and that opportunities for mental and social stimulation and time out of cell were provided.

The inspection team examined records and interviewed both prisoners and staff. It made 17 recommendations for improvements in the CSC and 21 in the HSE segregation units, and identified 17 areas of good practice. Only one recommendation was rejected.

This review illustrates the constructive role that an independent inspectorate can have, opening up to scrutiny an otherwise hidden part of a closed prison system where the potential for over-control by staff and of consequent prisoner deterioration is high. Where the prison system is also a mature user of inspection and makes good use of the findings, the process can result in positive outcomes for prisoners.

Prison inspections may also be carried out by regional bodies. In Europe, for example, the Committee for the Prevention of Torture (CPT), whose reports we have referred to throughout the Sourcebook, may visit any place of detention within the jurisdiction of Member States. International bodies charged with inspecting and monitoring places of detention include the International Committee of the Red Cross (ICRC), which is mandated to visit any place of detention in situations of armed conflict, and the UN Special Rapporteur on Torture and other Cruel, Inhuman or Degrading Treatment or Punishment. The Optional Protocol to the UN Conventions Against Torture (OPCAT) establishes both an international body of experts to conduct preventative visits to any place of deprivation of liberty in State parties (see above), and a National Preventative Mechanism, which is an independent body tasked with regular and ongoing preventative visits to any place of deprivation of liberty in that country. 


\section{Notes}

86 See: Association for the prevention of torture (APT), Monitoring Places of Detention: A Practical Guide. Geneva, April 2004; HM Chief Inspectorate of Prisons, Expectations: criteria for assessing the condition in prisons and the treatment of prisoners (updated regularly). 


\section{$7 \mid$ Summary of recommendations}

A number of common themes emerge from the various sources examined in the Sourcebook: a) Solitary confinement is an extreme and potentially harmful measure; b) Its use should be reserved for a handful of exceptional cases; c) Periods in solitary confinement should be as short as possible, and; d) Where prisoners are isolated they must be held in decent conditions and offered access to meaningful human contact and to purposeful activities. The deprivations inherent in solitary confinement should not be made worse by further restrictions on family visits and in-cell provisions such as books and magazines, craft and hobby materials, personal radios and so on. These may help to mitigate the harmful aspects of solitary confinement.

It is also clear that there are currently lacunae in international safeguards and protections against the misuse of solitary confinement and its negative health effects. Further development of international human rights standards is thus necessary, building on the United Nations' call from 1990 to abolish the use of solitary confinement (Principle 7 of the UN Basic Principles for the Treatment of Prisoners). To this end, on December 9th 2007, a working group of 24 international experts adopted the Istanbul Expert Statement on the Use and Effects of Solitary Confinement, calling on States to limit the use of solitary confinement to very exceptional cases, for as short a time as possible and only as a last resort (see Appendix 2). Other such efforts should be initiated by experts, international bodies, and States

Specific recommendations that this Sourcebook makes include:

\section{Procedural safeguards}

- Inform prisoners, in writing, of the reason for their segregation and its duration.

- Allow prisoners to make representations on their case at a formal hearing.

- Undertake regular reviews of placement - substantive and at short intervals.

These safeguards apply to all forms of solitary confinement.

\section{Placement in solitary confinement}

- When used as punishment for prison offences, solitary confinement must only be used as a last resort, and then for the shortest time possible, lasting days rather than weeks or months.

- The use of prolonged solitary confinement for managing prisoners is rarely justified, and then only in the most extreme of cases. 
- Those suffering from mental illness must not be placed in solitary confinement and under no circumstances should the use of solitary confinement serve as a substitute for appropriate mental health care.

- The use of solitary confinement for pre-charge and pre-trial detainees must be strictly limited by law and must only be used in exceptional circumstances, with judicial oversight, for as short a time as possible, and never for more than a matter of days.

- Solitary confinement must not be imposed indefinitely, and prisoners should know in advance its duration.

- The use of solitary confinement as a means of coercing or 'softening up' detainees for the purpose of interrogation should be prohibited.

\section{Physical conditions and regime:}

- Provide decent accommodation (as per established standards discussed in chapter 4), reflecting the fact that prisoners will spend most of their day in their cell.

- Provide educational, recreational and vocational programmes.

- Provide these activities, wherever possible, in association with others.

- Allow in-cell reading, hobbies and craft materials.

- Ensure that prisoners have regular human contact; encourage informal communication with staff.

- Allow regular and open family visits.

- Enable prisoners a degree of control of their daily lives and physical environment.

- Include a progressive element.

\section{Health}

- Health staff must maintain the same standards of care and ethical behaviour as those which apply outside the prison, in particular the right to health care and to privacy and confidentiality.

- Health staff must not participate in the decision to impose or the enforcement of any disciplinary measure.

- Provide mental health training for custodial staff 


\section{Appendix 1}

\section{Selected texts}

\section{European Prison Rules, Council of Europe Committee of Ministers Recommendation Rec (2006)2}

43.2 The medical practitioner or a qualified nurse reporting to such a medical practitioner shall pay particular attention to the health of prisoners held under conditions of solitary confinement, shall visit such prisoners daily, and shall provide them with prompt medical assistance and treatment at the request of such prisoners or the prison staff.

43.3 The medical practitioner shall report to the director whenever it is considered that a prisoner's physical or mental health is being put seriously at risk by continued imprisonment or by any condition of imprisonment, including conditions of solitary confinement.

$\ldots$

60.5 Solitary confinement shall be imposed as a punishment only in exceptional cases and for a specified period of time, which shall be as short as possible.

Note 1 When this recommendation was adopted, and in application of Article 10.2c of the Rules of Procedure for the meetings of the Ministers' Deputies, the Representative of Denmark reserved the right of his government to comply or not with Rule 43, paragraph 2, of the appendix to the recommendation because it is of the opinion that the requirement that prisoners held under solitary confinement be visited by medical staff on a daily basis raises serious ethical concerns regarding the possible role of such staff in effectively pronouncing prisoners fit for further solitary confinement.

\section{UN Standard Minimum Rules}

31. Corporal punishment, punishment by placing in a dark cell, and all cruel, inhuman or degrading punishments shall be completely prohibited as punishments for disciplinary offences.

32. (1) Punishment by close confinement or reduction of diet shall never be inflicted unless the medical officer has examined the prisoner and certified in writing that he is fit to sustain it.

(2) The same shall apply to any other punishment that may be prejudicial to the physical or mental health of a prisoner. In no case may such punishment be contrary to or depart from the principle stated in rule 31.

(3) The medical officer shall visit daily prisoners undergoing such punishments and shall advise the director if he considers the termination or alteration of the punishment necessary on grounds of physical or mental health. 


\section{The Oath of Athens (International Council of Prison Medical Services, 1979)}

We, the health professionals who are working in prison settings, meeting in Athens on September 10,1979 , hereby pledge, in keeping with the spirit of the Oath of Hippocrates, that we shall endeavour to provide the best possible health care for those who are incarcerated in prisons for whatever reasons, without prejudice and within our respective professional ethics.

We recognize the right of the incarcerated individuals to receive the best possible health care.

We undertake:

1. To abstain from authorizing or approving any physical punishment.

2. To abstain from participating in any form of torture.

3. Not to engage in any form of human experimentation amongst incarcerated individuals without their informed consent.

4. To respect the confidentiality of any information obtained in the course of our professional relationships with incarcerated patients.

5. That our medical judgements be based on the needs of our patients and take priority

Principles of Medical Ethics relevant to the Role of Health Personnel, particularly Physicians, in the Protection of Prisoners and Detainees against Torture and Other Cruel, Inhuman or Degrading Treatment or Punishment

Adopted by General Assembly resolution 37/194 of 18 December 1982

\section{Principle 1}

Health personnel, particularly physicians, charged with the medical care of prisoners and detainees have a duty to provide them with protection of their physical and mental health and treatment of disease of the same quality and standard as is afforded to those who are not imprisoned or detained.

\section{Principle 2}

It is a gross contravention of medical ethics, as well as an offence under applicable international instruments, for health personnel, particularly physicians, to engage, actively or passively, in acts which constitute participation in, complicity in, incitement to or attempts to commit torture or other cruel, inhuman or degrading treatment or punishment. ${ }^{1}$

\section{Principle 3}

It is a contravention of medical ethics for health personnel, particularly physicians, to be involved in any professional relationship with prisoners or detainees the purpose of which is not solely to evaluate, protect or improve their physical and mental health. 


\section{Principle 4}

It is a contravention of medical ethics for health personnel, particularly physicians:

( a ) To apply their knowledge and skills in order to assist in the interrogation of prisoners and detainees in a manner that may adversely affect the physical or mental health or condition of such prisoners or detainees and which is not in accordance with the relevant international instruments; ${ }^{2}$

( b ) To certify, or to participate in the certification of, the fitness of prisoners or detainees for any form of treatment or punishment that may adversely affect their physical or mental health and which is not in accordance with the relevant international instruments, or to participate in any way in the infliction of any such treatment or punishment which is not in accordance with the relevant international instruments.

\section{Principle 5}

It is a contravention of medical ethics for health personnel, particularly physicians, to participate in any procedure for restraining a prisoner or detainee unless such a procedure is determined in accordance with purely medical criteria as being necessary for the protection of the physical or mental health or the safety of the prisoner or detainee himself, of his fellow prisoners or detainees, or of his guardians, and presents no hazard to his physical or mental health.

\section{Principle 6}

There may be no derogation from the foregoing principles on any ground whatsoever, including public emergency.

\section{Notes}

1 See the Declaration on the Protection of All Persons from Being Subjected to Torture and Other Cruel. Inhuman or Degrading Treatment or Punishment (resolution 3452 (XXX), annex).

2 Particularly the Universal Declaration of Human Rights (resolution 217 A (III)), the International Covenants on Human Rights (resolution 2200 A (XXI). annex), the Declaration on the Protection of All Persons from Being Subjected to Torture and Other Cruel, Inhuman or Degrading Treatment or Punishment (resolution 3452 (XXX), annex) and the Standard Minimum Rules for the Treatment of Prisoners (First United Nations Congress on the Prevention of Crime and the Treatment of Offenders: report by the Secretariat (United Nations publication, Sales No. E.1956.IV.4, annex I.A)). 


\section{Appendix 2}

\section{The Istanbul statement on the use and effects of solitary confinement}

Adopted on 9 December 2007 at the International Psychological Trauma Symposium, Istanbul.

\section{The purpose of the statement}

Recent years have seen an increase in the use of strict and often prolonged solitary confinement practices in prison systems in various jurisdictions across the world. This may take the form of a disproportionate disciplinary measure, or increasingly, the creation of whole prisons based upon a model of strict isolation of prisoners (1). While acknowledging that in exceptional cases the use of solitary confinement may be necessary, we consider this a very problematic and worrying development. We therefore consider it timely to address this issue with an expert statement on the use and effects of solitary confinement.

\section{Definition}

Solitary confinement is the physical isolation of individuals who are confined to their cells for twenty-two to twenty-four hours a day. In many jurisdictions prisoners are allowed out of their cells for one hour of solitary exercise. Meaningful contact with other people is typically reduced to a minimum. The reduction in stimuli is not only quantitative but also qualitative. The available stimuli and the occasional social contacts are seldom freely chosen, are generally monotonous, and are often not empathetic.

\section{Common practices of solitary confinement}

Solitary confinement is applied in broadly four circumstances in various criminal justice systems around the world; as either a disciplinary punishment for sentenced prisoners; for the isolation of individuals during an ongoing criminal investigation; increasingly as an administrative tool for managing specific groups of prisoners; and as a judicial sentencing. In many jurisdictions solitary confinement is also used as a substitute for proper medical or psychiatric care for mentally disordered individuals. Additionally, solitary confinement is increasingly used as a part of coercive interrogation, and is often an integral part of enforced disappearance (2) or incommunicado detention. 


\section{The effects of solitary confinement}

It has been convincingly documented on numerous occasions that solitary confinement may cause serious psychological and sometimes physiological ill effects (3). Research suggests that between one third and as many as 90 per cent of prisoners experience adverse symptoms in solitary confinement. A long list of symptoms ranging from insomnia and confusion to hallucinations and psychosis has been documented. Negative health effects can occur after only a few days in solitary confinement, and the health risks rise with each additional day spent in such conditions. Individuals may react to solitary confinement differently. Still, a significant number of individuals will experience serious health problems regardless of the specific conditions, regardless of time and place, and regardless of pre-existing personal factors. The central harmful feature of solitary confinement is that it reduces meaningful social contact to a level of social and psychological stimulus that many will experience as insufficient to sustain health and well being.

The use of solitary confinement in remand prisons carries with it another harmful dimension since the detrimental effects will often create a de facto situation of psychological pressure which can influence the pre-trial detainees to plead guilty.

When the element of psychological pressure is used on purpose as part of isolation regimes such practices become coercive and can amount to torture.

Finally solitary confinement places individuals very far out of sight of justice. This can cause problems even in societies traditionally based on the rule of law. The history of solitary confinement is rich in examples of abusive practices evolving in such settings. Safeguarding prisoner rights therefore becomes especially challenging and extraordinarily important where solitary confinement regimes exist.

\section{Human rights and solitary confinement}

The use of torture, cruel, inhuman or degrading treatment or punishment is absolutely prohibited under international law (Article 7 of the UN convention on Civil and Political Rights (ICCPR) and the UN convention against Torture (CAT), for example). The UN Human Rights Committee has stipulated that use of prolonged solitary confinement may amount to a breach of Article 7 of the ICCPR (General comment 20/44, 3. April 1992). The UN Committee against Torture has made similar statements, with particular reference to the use of solitary confinement during pre-trial detention. The UN committee on the Rights of the Child has furthermore recommended that solitary confinement should not be used against children (4). Principle 7 of the UN Basic Principles for the Treatment of Prisoners states that 'Efforts addressed to the abolition of solitary confinement as a punishment, or to the restriction of its use, should be undertaken and encouraged'. Jurisprudence of the UN Human Rights Committee has previously found a specific isolation regime to violate both article 7 and article 10 of the ICCPR (Campos v. Peru 9. January 1998). 
On a regional level, the European Court and former Commission on Human Rights, as well as the European Committee for the Prevention of Torture (CPT), have made it clear that the use of solitary confinement can amount to a violation of Article 3 of the ECHR (i.e. constitute torture, inhuman or degrading treatment), depending on the specific circumstances of the case, and the conditions and duration of detention. It has been recognised that "...complete sensory isolation coupled with total isolation, can destroy the personality and constitutes a form of inhuman treatment which cannot be justified by the requirements of security or any other reason" (5). The CPT has also stated that solitary confinement "can amount to inhuman and degrading treatment" and has on several occasions criticized such practices and recommended reform - i.e. either abandoning specific regimes, limiting the use of solitary confinement to exceptional circumstances, and/or securing inmates a higher level of social contact (6). The importance of developing communal activities for prisoners subjected to various forms of isolation regimes has for example been stressed (CPT, visit report Turkey, 2006, para. 43). Furthermore, the revised European Prison Rules of 2006 have clearly stated that solitary confinement should be an exceptional measure and, when used, should be for as short a time as possible(7).

The Inter-American Court of Human Rights has also stated that prolonged solitary confinement constitutes a form of cruel, inhuman or degrading treatment prohibited under Article 5 of the American Convention on Human Rights (Castillo Petruzzi et al., Judgment of May 30, 1999).

\section{Policy implications}

Solitary confinement harms prisoners who were not previously mentally ill and tends to worsen the mental health of those who are. The use of solitary confinement in prisons should therefore be kept to a minimum. In all prison systems there is some use of solitary confinement - in special units or prisons for those seen as threats to security and prison order. But regardless of the specific circumstances, and whether solitary confinement is used in connection with disciplinary or administrative segregation or to prevent collusion in remand prisons, effort is required to raise the level of meaningful social contacts for prisoners.

This can be done in a number of ways, such as raising the level of prison staff-prisoner contact, allowing access to social activities with other prisoners, allowing more visits, and allowing and arranging in-depth talks with psychologists, psychiatrists, religious prison personnel, and volunteers from the local community. Especially important are the possibilities for both maintaining and developing relations with the outside world, including spouses, partners, children, other family and friends. It is also very important to provide prisoners in solitary confinement with meaningful in cell and out of cell activities. Research indicates that small group isolation in some circumstances may have similar effects to solitary confinement and such regimes should not be considered an appropriate alternative. 
The use of solitary confinement should be absolutely prohibited in the following circumstances:

- For death row and life-sentenced prisoners by virtue of their sentence.

- For mentally ill prisoners.

- For children under the age of 18.

Furthermore, when isolation regimes are intentionally used to apply psychological pressure on prisoners, such practices become coercive and should be absolutely prohibited.

As a general principle solitary confinement should only be used in very exceptional cases, for as short a time as possible and only as a last resort.

Notes

(1) For the purpose of this document we use the term prisoner as a broad category covering persons under any form of detention and imprisonment.

(2) The International Convention for the Protection of All Persons from Enforced Disappearance of December 2006 defines enforced disappearance as "...the arrest, detention, abduction or any other form of deprivation of liberty by agents of the State or by persons acting with the authorization, support or acquiescence of the State, followed by a refusal to acknowledge the deprivation of liberty or by concealment of the fate or whereabouts of the disappeared person, which place such a person outside the protection of the law."

(3) For studies on the health effects of solitary confinement, see Peter Scharff Smith "The Effects of Solitary Confinement on Prison Inmates. A Brief History and Review of the Literature" in Crime and Justice vol. 34, 2006 (pp. 441-528); Craig Haney "Mental Health Issues in Long-Term Solitary and 'Supermax' Confinement" in Crime \& Delinquency 49(1), 2003 (pp. 124-56); Stuart Grassian "Psychopathological Effects of Solitary Confinement" in American Journal of Psychiatry 140, 1983 (pp. 1450-4).

(4) CRC/C/15/Add.273, “Denmark”, 30 September 2005, para. 58 a.

(5) Ramirez Sanchez v. France, Grand Chamber, 4. July 2006, para. 123.

(6) Rod Morgan and Malcolm Evans "Combating torture in Europe", 2001, p. 118. See also Recommendation $\operatorname{Rec}(2003) 23$ Committee of Ministers under the European Council, para.7, 20, and 22.

(7) Committee of Ministers - Rec(2006)2E (Adopted by the Committee of Ministers on 11 January 2006 at the 952nd meeting of the Ministers' Deputies), article 60.5. See also CPT, GR2, §56. 


\section{Task group participants}

Alp Ayan, psychiatrist, Human Rights Foundation of Turkey

Türkcan Baykal, M.D., Human Rights Foundation of Turkey

Jonathan Beynon, M.D., Coordinator of health in detention, ICRC, Switzerland*

Carole Dromer, Médecins du Monde

Şebnem Korur Fincancı, Professor, Specialist on Forensic Medicine, Istanbul University, Turkey

Andre Gautier, Psychologist and psychoanalyst, ITEI-Bolivia

Inge Genefke, MD, DMSc hc mult, IRCT Ambassador, Founder of RCT and IRCT

Bernard Granjon, Médecins du Monde

Bertrand Guery, Médecins du Monde

Melek Göregenli, Professor in psychology, Psychology Dept., Ege University, Turkey

Cem Kaptanoğlu, Professor, psychiatrist, Osmangazi University, Turkey

Monica Lloyd, the Chief Inspector of Prisons office, United Kingdom*

Leanh Nguyen, Clinical Psychologist, Bellevue/NYU Program for Survivors of Torture

Manfred Nowak, Special Rapporteur on Torture, UN and Director of the Ludwig Boltzmann

Institute of Human Rights

Carol Prendergast, Director of Operations, Bellevue/NYU Program for Survivors of Torture

Christian Pross, M.D., Center for the Treatment of Torture Victims, Berlin, Germany

Sidsel Rogde, MD, PhD, Professor of Forensic Medicine, University of Oslo, Norway

Doğan Şahin, Ass. Professor, psychiatrist, Istanbul University, Turkey

Sharon Shalev, Mannheim Centre for Criminology, London School of Economics

Peter Scharff Smith, Senior Researcher, the Danish Institute for Human Rights

Alper Tecer, psychiatrist, Human Rights Foundation of Turkey

Hülya Üçpınar, legal expert, Human Rights Foundation of Turkey

Veysi Ülgen, M.D., TOHAV

Miriam Wernicke, Legal Adviser, IRCT

* The points of view expressed are the personal opinions of the individuals, and do not necessarily represent the position of their organizations. 


\section{Acronyms and abbreviations}

\begin{tabular}{ll}
\hline BMA & British Medical Association \\
\hline CAT & Committee against Torture \\
\hline CSC & Committee for the Prevention of Torture \\
\hline ECHR & European Convention on Human Rights \\
\hline ECtHR & European Court of Human Rights \\
\hline EPR & European Prison Rules \\
\hline HMCIP & Her Majesty's Chief Inspector of Prisons for England and Wales \\
\hline ICN & International Council of Nurses \\
\hline OPCAT & $\begin{array}{l}\text { Optional Protocol to the Convention against Torture and other Cruel, Inhuman or } \\
\text { Degrading Treatment or Punishment }\end{array}$ \\
\hline SMR & Standard Minimum Rules for the Treatment of Prisoners \\
\hline UN & United Nations \\
\hline WHO & World Health Organisation \\
\hline
\end{tabular}

WMA World Medical Association 


\section{Links \& Resources}

\section{Human rights bodies and legal instruments}

Office of the UN High Commissioner on Human Rights (OHCHR) www.ohchr.org

(Contains international law texts and materials and links to other UN bodies)

Committee for the Prevention of Torture (CPT) www.cpt.coe.int

(Contains country reports and CPT Standards)

European Court of Human Rights (ECtHR) www.echr.coe.int/echr

(Contains case law of the Court)

\section{Non-governmental organisations}

Amnesty International (Al) www.amnesty.org

Association for the Prevention of Torture (APT) www.apt.ch

Human Rights Watch (HRW) www.hrw.org

Prison Reform International (PRI) www.penalreform.org

\section{Professional Associations}

British Medical Association (BMA) www.bma.org.uk

British Psychological Association (BPS) www.bps.org.uk

International Council of Nurses (ICN) www.icn.ch

Royal College of Psychiatrists www.rcpsych.ac.uk

World Health Organisation (WHO) www.who.int

World Medical Association (WMA) www.wma.net

\section{England and Wales}

Her Majesty's Inspectorate of Prisons (HMCIP) http://inspectorates.homeoffice.gov.uk/hmciprisons

Prisons and Probation Ombudsman www.ppo.gov.uk

Prison Reform Trust (PRT) www.prisonreformtrust.org.uk

International Centre for Prison Studies www.kcl.ac.uk/schools/law/research/icps

Electronic copies of the Sourcebook on solitary confinement and additional links and resources can be found on the Solitary Confinement website: www.solitaryconfinement.org 


\section{Bibliography}

Abbott, J.H., (1982) In the Belly of the Beast: Letters from Prison. New York: Vintage Books.

Adams, R., (1994) Prison Riots in Britain and the USA. 2nd ed. London: Macmillan Press

All Parliamentary Group on Prison Health (2006) The Mental Health Problem in UK HM Prisons.

Amnesty International, (1980) Prison Conditions of Persons Suspected or Convicted of Politically Motivated Crimes in the FRG: Isolation and Solitary Confinement. Al Index: EUR 32/01/80.

Andersen, H.S., Sestoft, D., Lillebaek, T., Gabrielsen, G., Hemmingsen, R. (2003) A longitudinal study of prisoners on remand. Repeated measures of psychopathology in the initial phase of solitary versus nonsolitary confinement. International Journal of Law and Psychiatry, 26:165-177.

Association for the prevention of torture (APT), Monitoring Places of Detention: A Practical Guide. Geneva, April 2004

Benjamin, T.B. and Lux, K., (1977) Solitary Confinement as Psychological Punishment. California Western Law Review, 13:265-296.

Binda, H., (1975) Effects of Increased Security on Prison Violence. Journal of Criminal Justice, 3:33-46.

Bottoms, A.E., (1999) Interpersonal Violence and Social Order in Prisons. IN: Tonry, M. and Petersilia, J., eds. Crime and Justice: a review of research. Vol. 26, Prisons. Chicago and London: University of Chicago Press.

Briggs et al. (2003). 'The effects of supermaximum security prisons on aggregate levels of institutional violence,', Criminology, Vol.41 (4) pp 1341-1376.

British Medical Association Ethics Department, (2004) Medical Ethics Today.

British Medical Association (2001) The Medical Profession and Human Rights, London and New York: Zed Books.

Brodsky, S.L., and Scogin, F.R., (1988) Inmates in Protective Custody: First Data on Emotional Effects. Forensic Reports 1:267-280

Buchanan, R.A., Unger, C.A. and Whitlow, K.L., (1988) Disruptive Maximum Security Inmate Management Guide. Washington DC: US Department of Justice, National Institute of Corrections.

Campaign to Stop Control Units Report, 1997

Charriere, H., (1970) Papillon. London: Panther Books.

Cloyes, K.G., Lovell, D., Allen, D.G., Rhodes, L.A. (2006) Assessment of psychological impairment in a supermaxium security sample. Criminal Justice and Behavior, Vol. 33(6):760-781.

Cohen, S. and Taylor, L., ([1972]1981) Psychological Survival: The Experience of Long-Term Imprisonment. 2nd ed. Harmondsworth, Penguin Books. 
Coid, J., Petruckevitch, A., Bebbington, P., Jenkins, R., Brugha, T., Lewis, G., Farrell, M., Singleton, N. (2003). Psychiatric morbidity in prisoners and solitary cellular confinement, I: disciplinary segregation. Journal of Forensic Psychiatry \& Psychology, Vol. 14 No. 2:298-319, September.

Coid, J., Petruckevitch, A., Bebbington, P., Jenkins, R., Brugha, T., Lewis, G., Farrell, M., Singleton, N. (2003). Psychiatric morbidity in prisoners and solitary cellular confinement, ll: special ('strip') cells. Journal of Forensic Psychiatry \& Psychology, Vol. 14 No. 2:320-340, September.

Colvin, M., (1992) The Penitentiary in Crisis- From Accommodation to Riot in New Mexico. Albany: State University of New-York Press.

Commission on Safety and Abuse in America's Prisons: Confronting Confinement, June 2006.

Coyle, A. (2002), A Human Rights Approach to Prison Management, International Centre for Prison Studies, London.

Evans, R. (1982) The Fabrication of Virtue: English prison Architecture 1750-1840. Cambridge: Cambridge University Press.

Ecclestone, C., Gendreau, P. and Knox, C., (1974) Solitary confinement of prisoners: an assessment of its effects on inmates' personal constructs and adrenocortical activity. Canadian Journal of Behavioural Science Review, 6(2):178-191.

Fairweather, L. (2000) Psychological effects of the prison environment. IN: Fairweather, L. and McCnoville, S., eds. (2000) Prison Architecture: Policy, Design and Experience. London: Architectural Press.

Faris, R.E., (1934) Cultural Isolation and the Schizophrenic Personality. American Journal of Sociology, September, 40(2):155-164.

Gendreau, P. and Bonta, J., (1984) Solitary confinement is not Cruel and Unusual Punishment: People Sometimes Are! Canadian Journal of Criminology, 26:467-478.

General Medical Council, Good Practice Guidance on Confidentiality: Protecting and Providing Information, April 2004.

Goffman, E. (1961) Asylums: Essays on the social situation of mental patients and other Inmates. Garden City, New York: Anchor Books.

Grassian, S., (1983) Psychopathological Effects of Solitary Confinement. American Journal of Psychiatry, 140(11):1450-1454.

Grassian, S. and Friedman N., (1986) Effects of Sensory Deprivation in Psychiatric Seclusion and Solitary Confinement. International Journal of Law \& Psychiatry, 8:49-65.

Grassian, S. (2006) Psychiatric Effects of Solitary Confinement, Journal of Law and Policy, Vol.22:325-383. Haney (2003) Mental Health Issues in Long-Term Solitary and 'Supermax' Confinement. Crime \& Delinquency, 49(1):124-156.

Haney, C. and Lynch, M., (1997) Regulating Prisons of the Future: Psychological Analysis of Supermax and Solitary Confinement. New York University Review of Law \& Social Change, XXIII (4):477-570. 
Hills, H., Siegfried, C., Ickowitz, A. (2004) Effective Prison Mental Health Services: guidelines to expand and improve treatment. U.S. Department of Justice National Institute of Corrections.

Hocking, F., (1970) Extreme environmental stress and its significance for psychopathology, American Journal of Psychiatry, 24:4-26.

Hodgins, S. and Cote, G., (1991) The Mental health of penitentiary inmates in isolation. Canadian Journal of Criminology, April 1991:175-182.

Hunt, G. et al., (1999) Changes in Prison Culture: Prison Gangs and the Case of the Pepsi Generation. Soc. Prob. Issue 40.

HM Chief Inspectorate of Prisons for England and Wales, Expectations: criteria for assessing the condition in prisons and the treatment of prisoners (updated regularly).

Human Rights Watch, "Like the Dead in Their Coffins" Torture, Detention and the Crushing of Dissent in Iran; June 2004, Vol. 16, No.2 (E)

Human Rights Watch, Locked Up Alone: Detention Conditions and Mental Health at Guantanamo, June 2008.

Joint Parliamentary Committee on Human Rights (2004) Third Report Session 2004-05, HL 15/I/HC 137-I.

Korn, R. (1988) The effects of confinement in the High Security Unit at Lexington. Social Justice, 15(1):8-19

Kupers, T. (1999) Prison Madness: The Mental Health Crisis Behind Bars and What we Must do about it. San Francisco: Jossey-Bass.

McCleery, R., (1961) Authoritarianism and the Belief System of the Incorrigibles. IN: Cressey, D., (ed.) The Prison. New York: Holt, Rinehart and Winston, pp.260-306.

McConville, S., (1981) A History of English Prison Administration. London: Routledge and Kegan.

Mead, G. H., (1934) Mind, Self and Society. Chicago: University of Chicago Press.

Miller, H. (1994) Reexamining Psychological Distress in the Current Conditions of Segregation. Journal of Correctional Health Care, Vol. 1:39-53

Miller, H. and Young, G. (1997) Prison segregation: administrative detention remedy of mental health problem? Criminal Behaviour and Mental Health, Vol. 7:85-94

Morgan, R. and Evans, M. (2001) Combating torture in Europe. Strasburg: Council of Europe Publishing.

Morris, N. and Rothman, D., eds. (1998) The Oxford History of the Prison: The Practice of Punishment in Western Society. Oxford: Oxford University Press

Mottram, P. (2007) HMP Liverpool, Styal and Hindley Study Report, University of Liverpool

Moyer, F., (1975) The Architecture of closed institutions. IN: United Nations Social Defence Research Institute (UNSDRI) Prison Architecture: An International Survey of Representative and Closed Institutions and Analysis of Current Trends in Prison Design (prepared by G.D. Gennarro). London: The Architectural Press, pp.53-66.

Murdoch, J. (2006) The treatment of prisoners: European Standards. Strasburg: Council of Europe Publishing. 
National Offender Management Service, Safer Custody Group. Self Inflicted Deaths Annual Report $2004 / 5$.

Nitsche, P., and Williams, K., (1913) The History of the Prison Psychosis. Nervous and Mental Disease Monograph Series, No.13. New York: Nervous and Mental Disease Publishing Company.

Office of the United Nations High Commissioner for Human Rights (2005) Human Rights and Prisons, Professional Training Series No.11, available online at: www.ohchr.org

Parenti, C. (1999) Lockdown America: Police and Prisons in the Age of Crisis. London: Verso.

Physicians for Human Rights and the School of Public Health and Primary Health Care University of Cape Town (2002) Dual Loyalty \& Human Rights in Health Profession Practice. A Project of the International Dual Loyalty Working Group

Physicians for Human Rights (PHR) (2005) Break them down: systematic use of psychological torture by US forces Physicians for Human Rights, USA.

Prison Reform International (2003) Training Manual no. 1: Human Rights and Vulnerable Prisoners Rasmussen, J. (Ed.) (1973) Man in Isolation \& Confinement, Chicago: Aldine Publishing Company Reyes, $H$. The worst scars are in the mind: psychological torture, International Review of the Red Cross, Volume 89 No. 867 September 2007 pp 591-617.

Rickford, D. and Edgar, K. Troubled Inside: Responding the Mental Health Needs of Men in Prison, Prison Reform Trust, 2005

Riveland, C., (1999) Supermax prisons: Overview and General Considerations. Washington DC: US Department of Justice, National Institute of Corrections

Rhodes, L.A. (2004) Total confinement: madness and reason in the maximum security prison. Berkley and Los Angeles: University of California Press.

Robbins et al. (2005), Psychiatric problems of detainees under the Anti-Terrorism Crime and Security Act 2001. Royal College of Psychiatrists, Psychiatric Bulletin 29:407-409

Rothman, D.J. (1980) Conscience and Convenience: The Asylum and its Alternatives in Progressive America. Boston: Little, Brown and Company.

Royal College of Psychiatrists (2006) Good Psychiatric Practice: Confidentiality and Information Sharing, CR 133.

Royal College of Psychiatrists (1998) Management of imminent violence, OP 41.

Scharff-Smith, P., (2004) A Religious Technology of the Self: rationality and religion in the rise of the modern penitentiary. Punishment and Society, 6(2):195-220.

Scharff-Smith, P., (2006) "The Effects of Solitary Confinement on Prison Inmates. A Brief History and Review of the Literature" Crime and Justice Vol. 34:441-528

Scott, G.D. and Gendreau, P., (1969) Psychiatric Implications of Sensory Deprivation in a Maximum Security Prison. Canadian Psychiatric Association Journal, 14(1):337-341. 
Shalev, S (2009) Supermax: controlling risk through solitary confinement. Devon: Willan Publishing Shalev, S. (2007) "The power to classify: avenues into a supermax prison" in: Downes, D., Rock, P., Chinkin, C. and Gearty, C. (Eds.) Crime, Social Control and Human Rights: From moral panics to states of denial, Devon: Willan Publishing, pp. 107-119.

Sestfot, D.M., Andersen, H.S., Lillebaek. T. and Gabrielsen, G., (1998) Impact of solitary confinement on hospitalisation among Danish prisoners in custody. International Journal of Law and Psychiatry, 21(1):99-108.

Siegel, R., (1984) Hostage Hallucinations: Visual Imagery Induced by Isolation and Life-Threatening Stress. Journal of Nervous and Mental Disease, 17(5):264-272.

Smith, S. and Lewty, W., (1959) Perceptual isolation using a silent room. Lancet, 2:342-345.

Solomon, P. et al., eds. Sensory Deprivation. Cambridge, Mass: Harvard University Press.

Suedfeld, P., (1975) The Benefits of Boredom: Sensory Deprivation Reconsidered. American Scientist, JanFeb, 63:60-69.

Suedfeld, P. and Roy, C., (1975) Using Social Isolation to Change the Behaviour of Disruptive Inmates. International Journal of Offender Therapy and Comparative Criminology, 19:90-99.

Suedfeld, P., Ramirez, C., Deaton, J. and Baker-Brown, G., (1982) Reactions and Attributes of Prisoners in Solitary Confinement. Criminal Justice and Behaviour, 9(3):303-340.

Sutherland, E.H., and Cressey, D.R., (1955) Principles of criminology, 5th Ed. New York: J.B. Lippincott Company.

Sykes, G., (1958) The Society of Captives: A Study of Maximum Security Prison. Princeton: Princeton University Press

Toch, H (1992) Mosaic of Despair: Human Breakdown in Prison. Washington DC: American Psychological Association.

UN Human Rights Committee (2001) A/56/156.

UN Human Rights Committee, Concluding Remarks on Denmark. 31/10/2000. CCPR/CO/70/DNK

UN Special Rapporteur on the question of torture and other cruel, inhuman or degrading treatment or punishment Report (1999) UN doc. A/54/426

UN Special Rapporteur on the question of torture and other cruel, inhuman or degrading treatment or punishment Report (1995) UN doc. E/CN.4/1995/34

Wakefield, D., (1980) A Thousand Days of Solitary. London: National Prisoners' Movement (PROP).

Walters, R.H., Callagan, J.E. and Newman, A.F., (1962) The effects of solitary confinement on prisoners. American Journal of Psychiatry, 119(5):771-773.

World Health Organisation (WHO) Health in Prisons: a WHO Guide to the essentials in prison health. 2007 Zuckerman, M., (1964) Perceptual isolation as a stress situation. Archives of General Psychiatry, pp.255-276. 
Mannheim Centre for Criminology

London School of Economics

and Political Science

Houghton Street

London WC2A 2AE

UK

Produced with the assistance of the Nuffield Foundation

ISBN 978-0-85328-314-0

October 2008 